\title{
The Incidence of Perioperative Stroke: Estimate Using State and National Databases and Systematic Review
}

\author{
Rami Al-Hader, ${ }^{\mathrm{a}, \mathrm{b}}$ Khalid Al-Robaidi, ${ }^{\mathrm{a}, \mathrm{b}}$ Tudor Jovin, ${ }^{\mathrm{b}, \mathrm{c}}$ Ashutosh Jadhav, ${ }^{\mathrm{b}, \mathrm{c}}$ Lawrence R. Wechsler, ${ }^{\mathrm{b}, \mathrm{c}}$ \\ Parthasarathy D. Thirumala ${ }^{\mathrm{a}, \mathrm{b}, \mathrm{c}}$

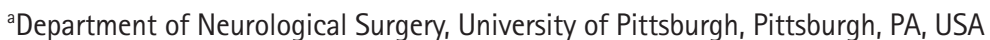 \\ 'University of Pittsburgh School of Medicine, Pittsburgh, PA, USA \\ 'Department of Neurology, University of Pittsburgh, Pittsburgh, PA, USA
}

Background and Purpose Perioperative stroke remains a devastating complication after surgical procedures, due to hemodynamic and inflammatory changes that increase the risk of strokes within 30 days following surgery. We aimed to assess the incidence of perioperative strokes in patients undergoing various surgical procedures and reach a national estimate.

Methods A retrospective cohort study was conducted using California State Inpatient Databases, State Emergency Department Databases, State Ambulatory Surgery and Services Databases, and the National Inpatient Sample (NIS) during the period 2008 to 2011 from the Healthcare Cost and Utilization Project. A systematic review was conducted using PubMed, Embase, and Web of Science databases to obtain published articles that reported the incidence of perioperative stroke in various surgical procedures.

Results Analysis of 3,694,410 surgical encounters from the state of California (mean \pm standard deviation age: $52.4 \pm 21.1$ years) yielded an overall rate of perioperative stroke of $0.32 \%$ $(n=11,759)$. The incidence of perioperative strokes was highest following neurological $(1.25 \%)$, vascular $(1.07 \%)$, and cardiac $(0.98 \%)$ surgeries. The NIS database contained a total of $48,672,974$ weighted hospitalizations and yielded a rate of perioperative stroke of $0.42 \%$ $(n=204,549)$. The systematic review completed yielded 187 articles, which had an overall sample size of 184,922 and an incidence of perioperative stroke ranging from $0 \%$ to $13.86 \%$. It is estimated that in any given year, there would be approximately 40,000 to $55,000(0.33 \%$ to $0.46 \%$ ) perioperative strokes nationally.

Conclusions Our findings support further strategies to identify and stratify patients undergoing surgical procedures with a high incidence of perioperative strokes to improve patient counseling and a future potential treatment plan.
Correspondence: Parthasarathy D. Thirumala

Department of Neurological Surgery, University of Pittsburgh, UPMC Presbyterian-Suite B-400, 200 Lothrop Street, Pittsburgh, PA 15213, USA Tel: +1-412-648-2228

Fax: +1-412-383-9899 E-mail: thirumalapd@upmc.edu

Received: February 1, 2019 Revised: June 24, 2019 Accepted: August 22, 2019

Keywords Stroke; Postoperative complications; Incidence; Surgery; Perioperative period 


\section{Introduction}

Perioperative stroke, a new neurological deficit that occurs during or within 30 days of surgery, ${ }_{1}^{1}$ is a devastating complication because it is associated with significant clinical burden and mortality..$^{1-3}$ The vast majority of these strokes are ischemic, and about $1 \%$ to $4 \%$ are hemorrhagic. ${ }^{2,45}$ The majority of the strokes (50\%) occur within the first postoperative day. ${ }^{3,6}$

The incidence of perioperative stroke varies among different types of surgical procedures, as it ranges approximately from $1.9 \%$ to $9.7 \%$ in high-risk cardiovascular surgeries, e.g., coronary artery bypass grafting (CABG) surgeries have a perioperative stroke rate of $3 \%$ to $5 \%{ }^{7}$ compared to $0.1 \%$ to $1.9 \%$ in non-cardiovascular, non-neurological and minor vascular surgeries. ${ }^{1,3,8}$ This variation in incidence is attributed to the surgical procedure itself as well as the associated risk factors and comorbidities. ${ }^{2}$ The incidence of perioperative stroke has not changed over the past two decades despite an improvement in medical and surgical care., ${ }^{2,9}$

The primary objective of the present study was to estimate the national incidence of perioperative strokes in patients undergoing various surgical procedures. We achieved this objective through analysis of a state-wide database and stratifying included patients according to their comorbidities and demographic variables, including age, sex, and ethnicity. We further estimated the incidence of perioperative stroke with results from the National Inpatient Sample (NIS) database. Finally, we performed a systematic review for all published studies reporting the incidence of perioperative stroke following various surgical procedures; this review has helped to solidify the calculated estimate we have reached using our databases. We expect the results of the study to improve the recognition and diagnosis of perioperative stroke and patient safety, which will help us estimate the financial cost and burden of perioperative stroke, as well as, pave the road for optimizing therapeutic and preventive measures that could be implemented to minimize the incidence of perioperative stroke.

\section{Methods}

\section{Data source}

Informed consent was not required by the The Institutional Review Board (IRB) at our institution for this retrospectic cohory analysis. Data were obtained from the Healthcare Cost and Utilization Project (HCUP) including State Inpatient Databases (SID), State Emergency Department Databases (SEDD), and State Ambulatory Surgery and Services Databases (SASD) for the state of California, and NIS during the 2008 to 2011 period. The SID, SEDD, and SASD contain the universe of the inpatient, emer- gency department (ED) and outpatient unit discharge abstracts and a set of clinical and nonclinical information on about $97 \%$ of patients discharged from different medical facilities in California. We chose the California state databases as they contain present on admission (POA) indicator; which is defined as the conditions present when the inpatient admission occurs. ${ }^{10}$ The POA indicator helps to differentiate strokes occurring in patients as a complication following surgery from those presented on admission with a stroke or history of stroke. The NIS contains data from all-payer inpatient health care in the United States, yielding national estimates of hospital inpatient stays.

\section{Patient and surgical procedure selection}

Patients in this study were those who underwent any surgical procedure from 2008 to 2011; this period was chosen because 2008 was one of the first years where the SID adopted using the POA indicators. The years 2010 and 2011 were chosen in Table 1 because claims databases tend to be very granular and improve yearly; therefore, presenting the most 2 recent years seemed most suited. Most patients undergoing any surgical procedure that did not require intubation and general anesthesia were excluded. Patients were identified according to their primary diagnosis, surgical procedure and comorbid risk factors using the International Classification of Diseases, 9th Revision, Clinical Modification (ICD-9-CM) and the Clinical Classification Software (CCS) which is a uniform and standardized coding system, that collapses the vast multitude of codes found in the ICD-9 into a smaller number of clinically meaningful categories.

Each specific surgical subcategory in Table 2 reflects one ICD9 code for one or more surgical procedure and intervention, the specific surgical procedure(s) for each subcategory are shown in Supplementary Table 1. The ICD-9 codes for the five subcategories were selected according to the combined highest procedure frequency, stroke number, and stroke incidence. Supplementary Tables 2-4 show the highest 100 surgical subcategories according to procedure frequency, stroke number, and stroke incidence respectively. Any results showing single digit number of cases were replaced by "**" to maintain patient privacy.

\section{Covariates}

The patients were identified into different categories according to hospital-level covariables, including age, sex, ethnicity, and specific comorbidities. Surgical procedures were stratified into 15 surgical categories according to the system involved. The age sub-groups were separated starting from 0 to 17 years, and from 18 to 25 years and every 5 years after that. Patients who suffered from perioperative stroke were identified according to the presence of at least one ICD-9 codes shown in Supplementary Table 5. 
Table 1. The incidence of perioperative stroke during 2010 to 2011 for both genders according to different age groups and races

\begin{tabular}{|c|c|c|c|c|c|c|}
\hline \multirow{2}{*}{ Variable } & \multicolumn{2}{|c|}{ Male } & \multicolumn{2}{|c|}{ Female } & \multirow{2}{*}{$\begin{array}{c}\text { Overall } \\
(n=2,537,251) \\
(2008-2011)\end{array}$} & \multirow{2}{*}{$\begin{array}{c}\text { NIS } \\
(n=48,672,974) \\
(2008-2011)\end{array}$} \\
\hline & 2010 & 2011 & 2010 & 2011 & & \\
\hline \multicolumn{7}{|l|}{ Age group (yr) } \\
\hline $0-17$ & $24(0.20)$ & $23(0.21)$ & $20(0.23)$ & $14(0.17)$ & $196(0.15)$ & $3,479(0.06)$ \\
\hline $18-25$ & $12(0.13)$ & $18(0.19)$ & $13(0.13)$ & $11(0.11)$ & $121(0.04)$ & $1,845(0.04)$ \\
\hline $26-30$ & $14(0.19)$ & ${ }^{*}(0.112)$ & $16(0.19)$ & $15(0.18)$ & $127(0.05)$ & $1,672(0.05)$ \\
\hline $31-35$ & $19(0.23)$ & $17(0.20)$ & ${ }^{*}(0.09)$ & $10(0.11)$ & $122(0.04)$ & $2,082(0.06)$ \\
\hline $36-40$ & $27(0.25)$ & $23(0.225)$ & $20(0.17)$ & $13(0.11)$ & $180(0.08)$ & $3,184(0.12)$ \\
\hline $41-45$ & $43(0.28)$ & $36(0.24)$ & $30(0.20)$ & $49(0.33)$ & $322(0.16)$ & $4,725(0.22)$ \\
\hline $46-50$ & $71(0.31)$ & $75(0.33)$ & $66(0.30)$ & $51(0.24)$ & $489(0.19)$ & $8,020(0.29)$ \\
\hline $51-55$ & $95(0.32)$ & $85(0.28)$ & $77(0.28)$ & $91(0.33)$ & $717(0.27)$ & $11,730(0.36)$ \\
\hline $56-60$ & $147(0.43)$ & $127(0.36)$ & $121(0.39)$ & $106(0.34)$ & $975(0.34)$ & $15,541(0.44)$ \\
\hline $61-65$ & $171(0.48)$ & $157(0.43)$ & $128(0.37)$ & $142(0.40)$ & $1,167(0.39)$ & $19,856(0.53)$ \\
\hline $66-70$ & $200(0.58)$ & $170(0.48)$ & $173(0.49)$ & $177(0.49)$ & $1,390(0.47)$ & $21,832(0.58)$ \\
\hline $71-75$ & $201(0.66)$ & $196(0.64)$ & $193(0.59)$ & $191(0.58)$ & $1,501(0.56)$ & $22,723(0.69)$ \\
\hline $76-80$ & $195(0.74)$ & $218(0.83)$ & $210(0.69)$ & $220(0.73)$ & $1,681(0.68)$ & $23,068(0.79)$ \\
\hline $81-85$ & $150(0.75)$ & $173(0.88)$ & $203(0.76)$ & $202(0.79)$ & $1,455(0.75)$ & $19,372(0.87)$ \\
\hline $86-90$ & $109(0.84)$ & $107(0.82)$ & $157(0.82)$ & $176(0.91)$ & $1,067(0.82)$ & $11,272(0.89)$ \\
\hline $91-95$ & $20(0.95)$ & $20(0.86)$ & $39(0.82)$ & $37(0.75)$ & $220(0.79)$ & 3,328 (0.89) \\
\hline $96-100$ & ${ }^{*}(1.92)$ & ${ }^{*}(0.47)$ & ${ }^{*}(0.94)$ & ${ }^{*}(0.66)$ & $25(0.68)$ & 495 (0.68) \\
\hline Total $^{+}$ & $1,502(0.48)$ & $1,454(0.46)$ & $1,481(0.45)$ & $1,510(0.46)$ & $11,755(0.32)$ & $174,287(0.35)$ \\
\hline \multicolumn{7}{|l|}{ Race } \\
\hline White & $874(0.46)$ & $827(0.44)$ & $881(0.44)$ & $883(0.45)$ & $6,889(0.35)$ & 107,795 (0.38) \\
\hline Black & $98(0.52)$ & $90(0.47)$ & $101(0.45)$ & $118(0.51)$ & $813(0.35)$ & $20,008(0.39)$ \\
\hline Hispanic & $296(0.47)$ & $272(0.42)$ & $264(0.41)$ & $282(0.42)$ & $2,162(0.26)$ & $11,417(0.24)$ \\
\hline Asian or Pacific Islander & $155(0.83)$ & $173(0.89)$ & $161(0.76)$ & $148(0.69)$ & $1,181(0.45)$ & $3,922(0.34)$ \\
\hline Native American & $0(0)$ & $0(0)$ & $0(0)$ & ${ }^{*}(1.04)$ & ${ }^{*}(0.23)$ & $864(0.31)$ \\
\hline Other & $33(0.58)$ & $44(0.68)$ & $25(0.48)$ & $42(0.68)$ & $275(0.38)$ & $4,763(0.32)$ \\
\hline Total $^{+}$ & $1,456(0.49)$ & $1,406(0.47)$ & $1,432(0.45)$ & $1,475(0.47)$ & $11,327(0.33)$ & $148,768(0.36)$ \\
\hline
\end{tabular}

Values are presented as number (\%). The overall incidence during 2008 to 2011 for the same age groups and races for California state (State Inpatient Databases [SID], State Emergency Department Databases [SEDD], and State Ambulatory Surgery and Services Databases [SASD] databases; $n=2,537,251)$ and National Inpatient Sample (NIS) databases $(n=48,672,974)$.

${ }^{*}$ Any results showing numbers less than 10 patients to maintain patient privacy; ${ }^{+}$In the data obtained, some patients had the age and race information reported as missing, which resulted in different totals in both categories.

\section{Outcomes}

The primary outcome of the present study is strokes that occurred within 30 days of surgical procedures that require intubation and general anesthesia.

\section{Systematic review}

A systematic review was conducted on the incidence of perioperative stroke after surgical procedures. It complied with the Preferred Reporting Items for Systematic Reviews and MetaAnalyses (PRISMA). The search criteria, inclusion and exclusion criteria, detailed data extraction information, and PRISMA flowchart, are found in Supplementary Material, Supplementa- ry Table 6, and Supplementary Figure 1.

PubMed, EMBASE, and Web of Science were used as the search databases for relevant literature. Two researchers (R.A. and E.J.) independently conducted the study search, and a third researcher (K.A.) settled any disagreements.

\section{Statistical analysis}

Dataset construction and analysis were done using the SAS program version 9.4 (SAS Institute Inc., Cary, NC, USA). Data in each year from 2008 to 2011 were merged into a shared database. Patient records were linked and tracked using VisitLink and DaysToEvents variables provided by HCUP. For patients 
Table 2. The incidence of perioperative stroke for the state of California in different surgical categories

\begin{tabular}{|c|c|c|c|c|c|}
\hline \multirow{2}{*}{ Surgical category } & \multicolumn{2}{|c|}{ Male } & \multicolumn{2}{|c|}{ Female } & \multirow{2}{*}{$\begin{array}{c}\text { Overall } \\
(2008-2011)\end{array}$} \\
\hline & 2010 & 2011 & 2010 & 2011 & \\
\hline Neurosurgery & $225(1.34)$ & $216(1.31)$ & $190(1.42)$ & $188(1.50)$ & $1,594(1.25)$ \\
\hline Ventricular shunt to extracranial site & $*(1.85)$ & ${ }^{*}(2.99)$ & ${ }^{*}(8.00)$ & * (10.91) & $23(5.65)$ \\
\hline Craniotomy and craniectomy; reopening of craniotomy site & ${ }^{*}(6.25)$ & ${ }^{*}(4.65)$ & * (12.82) & $0(0)$ & $18(5.49)$ \\
\hline Other incision of brain & $14(4.08)$ & $29(7.32)$ & $14(5.74)$ & $14(5.24)$ & $138(5.25)$ \\
\hline Other craniectomy & $*(4.55)$ & $12(8.05)$ & ${ }^{*}(6.20)$ & ${ }^{*}(2.13)$ & $46(4.56)$ \\
\hline Incision of cerebral meninges & $65(3.62)$ & $47(2.60)$ & $34(3.90)$ & $36(4.12)$ & $357(3.27)$ \\
\hline Cardiac & $446(0.90)$ & 434 (0.92) & $292(1.24)$ & $320(1.43)$ & $2,871(0.98)$ \\
\hline Insertion of implantable heart assist system & $*(4.44)$ & $*(3.45)$ & *(11.11) & ${ }^{*}(11.76)$ & $27(5.7)$ \\
\hline Open heart valvuloplasty of aortic valve without replacement & ${ }^{*}(3.97)$ & ${ }^{*}(4.67)$ & ${ }^{*}(8.00)$ & ${ }^{*}(6.41)$ & $31(4.22)$ \\
\hline Open and other replacement of aortic valve with tissue graft & $65(2.49)$ & $60(2.21)$ & $41(2.79)$ & $46(3.03)$ & $416(2.61)$ \\
\hline Implant of pulsation balloon & 24 (1.98) & $29(2.25)$ & $14(2.55)$ & ${ }^{*}(1.33)$ & $151(2.18)$ \\
\hline (Aorto)coronary bypass of three coronary arteries & $47(1.83)$ & $43(1.75)$ & $17(2.32)$ & $16(2.25)$ & $238(1.78)$ \\
\hline Vascular & $369(0.91)$ & $367(0.91)$ & $443(1.28)$ & $431(1.26)$ & $3,170(1.07)$ \\
\hline $\begin{array}{l}\text { Endovascular removal of obstruction from head and neck } \\
\text { vessel(s) }\end{array}$ & $27(17.88)$ & $25(18.25)$ & $34(26.56)$ & $36(24.49)$ & $171(18.47)$ \\
\hline Extracranial-intracranial vascular bypass & ${ }^{*}(20.69)$ & $*(0.09)$ & * (15.00) & $10(15.87)$ & $60(13.82)$ \\
\hline Clipping of aneurysm & $17(8.37)$ & $21(11.23)$ & $51(10.30)$ & $47(9.44)$ & $294(10.29)$ \\
\hline Endarterectomy; other vessels of head and neck & $56(1.45)$ & $59(1.59)$ & $49(1.86)$ & $57(2.31)$ & $433(1.59)$ \\
\hline Percutaneous transluminal coronary angioplasty & $111(0.39)$ & $109(0.41)$ & $81(0.63)$ & $103(0.86)$ & $761(0.46)$ \\
\hline Organ transplant & $10(1.72)$ & $10(1.63)$ & ${ }^{*}(2.56)$ & $11(2.94)$ & $74(1.90)$ \\
\hline Heart transplantation & ${ }^{*}(3.47)$ & $*(4.29)$ & ${ }^{*}(1.79)$ & $*(7.94)$ & $31(3.51)$ \\
\hline Combined heart-lung transplantation & $0(0)$ & $0(0)$ & $0(0)$ & $0(0)$ & ${ }^{*}(3.3)$ \\
\hline Bilateral lung transplantation & *(1.82) & *(1.69) & ${ }^{*}(4.17)$ & ${ }^{*}(1.82)$ & ${ }^{*}(1.58)$ \\
\hline Other transplant of liver & $*(1.25)$ & ${ }^{*}(0.60)$ & ${ }^{*}(3.19)$ & $*(1.97)$ & $31(1.48)$ \\
\hline Pancreatic transplant, not otherwise specified & $0(0)$ & $0(0)$ & $0(0)$ & $0(0)$ & ${ }^{*}(1.79)$ \\
\hline Respiratory/Thoracic & $61(0.43)$ & $48(0.33)$ & $54(0.42)$ & $68(0.52)$ & $428(0.39)$ \\
\hline Reopening of recent thoracotomy site & $0(0)$ & $0(0)$ & $*(13.33)$ & ${ }^{*}(7.14)$ & ${ }^{*}(2.78)$ \\
\hline Other and unspecified pneumonectomy & ${ }^{*}(3.03)$ & $0(0)$ & ${ }^{*}(2.99)$ & ${ }^{*}(3.92)$ & ${ }^{*}(1.55)$ \\
\hline Other lobectomy of lung & ${ }^{*}(0.55)$ & $*(0.45)$ & ${ }^{*}(0.75)$ & ${ }^{*}(0.38)$ & $37(0.57)$ \\
\hline Decortication of lung & ${ }^{*}(0.39)$ & ${ }^{*}(0.39)$ & ${ }^{*}(0.44)$ & ${ }^{*}(0.48)$ & $15(0.48)$ \\
\hline Thoracoscopic excision of lesion or tissue of lung & ${ }^{*}(0.44)$ & ${ }^{*}(0.27)$ & ${ }^{*}(0.36)$ & ${ }^{*}(0.54)$ & $31(0.37)$ \\
\hline Endocrine & $12(0.45)$ & $13(0.52)$ & $22(0.29)$ & $14(0.20)$ & $109(0.25)$ \\
\hline Partial excision of pituitary gland, transfrontal approach & ${ }^{*}(12.50)$ & $*(6.06)$ & ${ }^{*}(21.43)$ & ${ }^{*}(9.52)$ & $25(10.16)$ \\
\hline Partial excision of pineal gland & $0(0)$ & ${ }^{*}(33.33)$ & ${ }^{*}(16.67)$ & $0(0)$ & ${ }^{*}(3.13)$ \\
\hline Division of thyroid isthmus & $0(0)$ & $0(0)$ & * (33.33) & $0(0)$ & ${ }^{*}(3.77)$ \\
\hline Unilateral adrenalectomy & ${ }^{*}(0.57)$ & $0(0)$ & ${ }^{*}(0.40)$ & ${ }^{*}(0.38)$ & ${ }^{*}(0.33)$ \\
\hline Complete thyroidectomy & ${ }^{*}(0.14)$ & $0(0)$ & ${ }^{*}(0.03)$ & ${ }^{*}(0.04)$ & ${ }^{*}(0.04)$ \\
\hline Gastrointestinal & $153(0.23)$ & $119(0.18)$ & $168(0.20)$ & $178(0.21)$ & $1,193(0.19)$ \\
\hline Open total intra-abdominal colectomy & ${ }^{*}(0.40)$ & ${ }^{*}(0.36)$ & ${ }^{*}(1.44)$ & ${ }^{*}(0.77)$ & $17(0.98)$ \\
\hline Open and other left hemicolectomy & $*(0.56)$ & ${ }^{*}(1.11)$ & ${ }^{*}(1.03)$ & ${ }^{*}(0.79)$ & $56(0.83)$ \\
\hline Exploratory laparotomy & ${ }^{*}(0.35)$ & ${ }^{*}(0.38)$ & ${ }^{*}(0.81)$ & ${ }^{*}(0.98)$ & $28(0.64)$ \\
\hline Other partial resection of small intestine & $13(0.56)$ & $14(0.61)$ & $16(0.58)$ & $21(0.73)$ & $121(0.61)$ \\
\hline Cholecystectomy & $13(0.61)$ & ${ }^{*}(0.34)$ & ${ }^{*}(0.29)$ & ${ }^{*}(0.15)$ & $57(0.32)$ \\
\hline
\end{tabular}


Table 2. Continued

\begin{tabular}{|c|c|c|c|c|c|}
\hline \multirow{2}{*}{ Surgical category } & \multicolumn{2}{|c|}{ Male } & \multicolumn{2}{|c|}{ Female } & \multirow{2}{*}{$\begin{array}{c}\text { Overall } \\
(2008-2011\end{array}$} \\
\hline & 2010 & 2011 & 2010 & 2011 & \\
\hline Ophthalmic & $*(25)$ & ${ }^{*}(0.09)$ & ${ }^{*}(0.13)$ & $0(0)$ & $12(0.15)$ \\
\hline Other removal or destruction of corneal lesion & $*(100.00)$ & $0(0)$ & $0(0)$ & $0(0)$ & $*(9.9)$ \\
\hline Other extracapsular extraction of lens & $0(0)$ & (0) & $0(0)$ & $0(0)$ & ${ }^{*}(4.17)$ \\
\hline Other repair of retinal detachment & ${ }^{*}(10.00)$ & (0) & $0(0)$ & $0(0)$ & ${ }^{*}(2.78)$ \\
\hline Other operations on vitreous & $0(0)$ & (0) & $0(0)$ & $0(0)$ & $*(1.67)$ \\
\hline Suture of corneal laceration & $0(0)$ & (0) & $0(0)$ & $0(0)$ & ${ }^{*}(0.36)$ \\
\hline Blood/Lymphatic & ${ }^{*}(0.24)$ & ${ }^{*}(0.26)$ & $11(0.17)$ & $16(0.27)$ & $88(0.24)$ \\
\hline Total splenectomy & ${ }^{*}(0.19)$ & ${ }^{*}(0.56)$ & ${ }^{*}(0.96)$ & ${ }^{*}(0.68)$ & $23(0.56)$ \\
\hline Radical excision of periaortic lymph nodes & $0(0)$ & $0(0)$ & ${ }^{*}(0.64)$ & (0) & ${ }^{*}(0.55)$ \\
\hline Biopsy of lymphatic structure & ${ }^{*}(0.031)$ & ${ }^{*}(0.20)$ & ${ }^{*}(0.24)$ & ${ }^{*}(0.38)$ & $36(0.34)$ \\
\hline Radical neck dissection, unilateral & ${ }^{*}(0.45)$ & ${ }^{*}(0.15)$ & $0(0)$ & ${ }^{*}(0.61)$ & $10(0.24)$ \\
\hline Excision of axillary lymph node & $0(0)$ & $0(0)$ & $0(0)$ & ${ }^{*}(0.05)$ & ${ }^{*}(0.02)$ \\
\hline Musculoskeletal & $180(0.19)$ & $185(0.19)$ & $257(0.22)$ & $248(0.21)$ & $1,719(0.20)$ \\
\hline Amputation above knee & ${ }^{*}(0.60)$ & ${ }^{*}(0.58)$ & ${ }^{*}(1.50)$ & $*(1.29)$ & $53(1.06)$ \\
\hline Atlas-axis spinal fusion & ${ }^{*}(1.37)$ & ${ }^{*}(0.78)$ & ${ }^{*}(0.60)$ & ${ }^{*}(0.61)$ & $11(0.92)$ \\
\hline Other amputation below knee & ${ }^{*}(0.50)$ & $13(0.87)$ & $11(1.72)$ & ${ }^{*}(0.92)$ & $66(0.75)$ \\
\hline Partial hip replacement & $21(0.77)$ & $22(0.82)$ & $51(0.80)$ & $36(0.57)$ & $250(0.68)$ \\
\hline Open reduction of fracture with internal fixation; femur & $19(0.45)$ & $28(0.66)$ & $39(0.47)$ & $38(0.46)$ & $275(0.54)$ \\
\hline Urology & $24(0.18)$ & $38(0.29)$ & $22(0.20)$ & $17(0.16)$ & $214(0.22)$ \\
\hline Nephroureterectomy & ${ }^{*}(0.24)$ & ${ }^{*}(0.30)$ & ${ }^{*}(0.35)$ & ${ }^{*}(0.25)$ & $45(0.27)$ \\
\hline Percutaneous nephrostomy without fragmentation & ${ }^{*}(0.25)$ & ${ }^{*}(0.40)$ & ${ }^{*}(0.37)$ & ${ }^{*}(0.33)$ & $41(0.41)$ \\
\hline Radical cystectomy & ${ }^{*}(0.46)$ & ${ }^{*}(0.47)$ & ${ }^{*}(0.92)$ & $0(0)$ & $14(0.45)$ \\
\hline $\begin{array}{l}\text { Other transurethral excision or destruction of lesion or tissue } \\
\text { of bladder }\end{array}$ & ${ }^{*}(0.16)$ & ${ }^{*}(0.22)$ & ${ }^{*}(0.65)$ & $0(0)$ & $28(0.28)$ \\
\hline Control of (postoperative) hemorrhage of bladder & ${ }^{*}(0.82)$ & ${ }^{*}(3.57)$ & $0(0)$ & $0(0)$ & ${ }^{*}(0.96)$ \\
\hline Reproductive male & $12(0.06)$ & $22(0.10)$ & $0(0)$ & $0(0)$ & $66(0.08)$ \\
\hline Other transurethral prostatectomy & ${ }^{*}(0.08)$ & $11(20)$ & $0(0)$ & $0(0)$ & $33(0.13)$ \\
\hline Control of (postoperative) hemorrhage of prostate & $*(1.69)$ & ${ }^{*}(0.81)$ & $0(0)$ & $0(0)$ & ${ }^{*}(0.89)$ \\
\hline Radical prostatectomy & ${ }^{*}(0.05)$ & ${ }^{*}(0.07)$ & $0(0)$ & $0(0)$ & $12(0.04)$ \\
\hline Unilateral orchiectomy & $0(0)$ & ${ }^{*}(0.31)$ & $0(0)$ & $0(0)$ & ${ }^{*}(0.7)$ \\
\hline Removal of both testes at same operative episode & $0(0)$ & $0(0)$ & $0(0)$ & $0(0)$ & ${ }^{*}(0.56)$ \\
\hline OBGYN & $0(0)$ & $0(0)$ & $30(0.01)$ & $21(0.01)$ & $110(0.01)$ \\
\hline Low cervical cesarean section & $0(0)$ & $0(0)$ & $11(0.01)$ & $10(0.01)$ & $41(0.01)$ \\
\hline Other and unspecified total abdominal hysterectomy & $0(0)$ & $0(0)$ & ${ }^{*}(0.06)$ & $*(0.02)$ & $27(0.04)$ \\
\hline $\begin{array}{l}\text { Other removal of both ovaries and tubes at same operative ep- } \\
\text { isode }\end{array}$ & $0(0)$ & $0(0)$ & (0) & ${ }^{*}(0.13)$ & ${ }^{*}(0.11)$ \\
\hline Laparoscopic total abdominal hysterectomy & $0(0)$ & $0(0)$ & ${ }^{*}(0.03)$ & ${ }^{*}(0.04)$ & ${ }^{*}(0.03)$ \\
\hline Classical cesarean section & $0(0)$ & $0(0)$ & ${ }^{*}(0.12)$ & $0(0)$ & ${ }^{*}(0.6)$ \\
\hline Breast and skin & * $(0.019)$ & ${ }^{*}(0.19)$ & ${ }^{*}(0.05)$ & $11(0.10)$ & $52(0.08)$ \\
\hline Fat graft of skin and subcutaneous tissue & $0(0)$ & ${ }^{*}(3.23)$ & $0(0)$ & ${ }^{*}(2.17)$ & ${ }^{*}(2.06)$ \\
\hline Bilateral simple mastectomy & $0(0)$ & $0(0)$ & $0(0)$ & ${ }^{*}(0.34)$ & ${ }^{*}(0.8)$ \\
\hline Removal of implant of breast & $0(0)$ & $0(0)$ & $0(0)$ & $0(0)$ & ${ }^{*}(0.8)$ \\
\hline Other free skin graft to other sites & ${ }^{*}(0.27)$ & ${ }^{*}(0.17)$ & ${ }^{*}(0.47)$ & ${ }^{*}(0.15)$ & $15(0.21)$ \\
\hline Homograft to skin & ${ }^{*}(0.56)$ & $0(0)$ & $0(0)$ & $0(0)$ & ${ }^{*}(0.34)$ \\
\hline
\end{tabular}


Table 2. Continued

\begin{tabular}{|c|c|c|c|c|c|}
\hline \multirow{2}{*}{ Surgical category } & \multicolumn{2}{|c|}{ Male } & \multicolumn{2}{|c|}{ Female } & \multirow{2}{*}{$\begin{array}{c}\text { Overall } \\
(2008-2011)\end{array}$} \\
\hline & 2010 & 2011 & 2010 & 2011 & \\
\hline ENT & ${ }^{*}(0.12)$ & ${ }^{*}(0.18)$ & ${ }^{*}(0.17)$ & $*(0.22)$ & $59(0.15)$ \\
\hline Sphenoidectomy & $0(0)$ & ${ }^{*}(5.00)$ & * $(3.85)$ & $0(0)$ & ${ }^{*}(4.37)$ \\
\hline Incision of multiple nasal sinuses & $0(0)$ & ${ }^{*}(25.00)$ & $0(0)$ & $0(0)$ & ${ }^{*}(4.35)$ \\
\hline Sphenoidotomy & $0(0)$ & $0(0)$ & $0(0)$ & $0(0)$ & ${ }^{*}(3.31)$ \\
\hline Control of epistaxis by ligation of ethmoidal arteries & $0(0)$ & $0(0)$ & $0(0)$ & $0(0)$ & ${ }^{*}(2.7)$ \\
\hline Ethmoidectomy & ${ }^{*}(1.37)$ & $0(0)$ & $0(0)$ & ${ }^{*}(1.54)$ & ${ }^{*}(0.62)$ \\
\hline
\end{tabular}

Values are presented as number (\%). The incidence of perioperative stroke for the state of California in different surgical categories with five subcategories that had the combined highest procedure frequency, stroke number, and stroke incidence according to their International Classification of Diseases, Ninth Revision (ICD-9) codes in 2010 and 2011 for both sexes, as well as their incidence during 2008 to 2011.

OBGYN, obstetrics and gynecology; ENT, ear, nose, throat.

${ }^{*}$ Any results showing numbers less than 10 patients to maintain patient privacy.

with multiple admissions and surgeries, only the first record was considered for analysis. The cases that were lacking values for age, gender, and race were not excluded in our final dataset as they composed a sizable portion of the data. Descriptive data characteristics were presented as mean \pm standard deviation or as a number of cases with their percentages.

CCS codes available on the HCUP website were used to group surgical procedures into different categories. ICD-9 procedural codes were used for surgical subgroup analysis. We created an array that searches through every record's diagnoses variable 2 to 25 with negative POA variable. The negative POA variable helps us differentiate between cases of stroke developing during the inpatient hospital stay and cases of stroke that was present at the time of admission, and therefore, eliminating the latter. We performed univariate analyses using an unpaired t-test for continuous variables and Pearson's chisquare test for categorical variables.

The HCUP uses databases as samples used to represent a larger universe. To generate a national estimate using the NIS database, a process called data weighting must be performed on the discharge or hospital weights from unweighted counts, ${ }^{11}$ which was performed and stratified using the strata variable provided by HCUP. NIS databases do not contain the POA variable, which made it impossible to identify cases of stroke that happened before the studied surgical admission.

\section{Results}

\section{Patient characteristics}

\section{California state database}

A total of $3,694,410$ patients who underwent various surgical procedures during 2008 to 2011 were identified from the SID,
SASD, and SEDD. In the present dataset, $63.21 \%$ of the cases were females $(n=2,267,321)$ with cases missing values for gen$\operatorname{der}(n=107,537,2.91 \%)$, the largest age and racial groups were those between 61 to 65 years of age $8.21 \%(n=300,779)$ and white $58.44 \%(n=1,991,270)$ with cases missing values for age $(n=31,294,0.85 \%)$ and race $(n=287,191,7.77 \%)$.

Patients who suffered from a perioperative stroke were older (67.6 \pm 16.7 years vs. $52.4 \pm 21.1$ years) and more likely to be females $(50.9 \%, P<0.01)$. However, the incidence of perioperative stroke was higher in males $(0.44 \%$ vs. $0.26 \%)$ because of the high number of obstetrics and gynecology (OBGYN) surgeries that had a low total incidence of perioperative stroke (Table 2). The most prevalent comorbidities in patients from this dataset were hypertension $(n=1,445,794,39.13 \%)$, iron deficiency anemia $(n=571,964$, $15.48 \%)$, and uncomplicated diabetes $(n=457,844,12.39 \%)$.

\section{NIS database}

From the NIS database, a total of $48,672,974$ weighted hospitalizations were obtained during 2008 to $2011,58.0 \%$ of the cases were females $(n=27,984,592)$, and the largest age and racial groups were those between 0 to 17 years of age $11.71 \%$ $(n=5,701,621)$ and white $69.1 \%(n=28,643,738)$, while cases missing values for race comprised a proportion of the cohort, we were not able to obtain the number of those missing cases after data weighting. The patients who suffered from a perioperative stroke were older ( $65.1 \pm 17.5$ years vs. $47.4 \pm 24.9$ years), and the incidence of perioperative stroke was higher in males $(0.43 \%$ vs. $0.31 \%)$.

\section{Systematic review}

The systematic review performed, without a meta-analysis, yielded 187 papers, with a total cohort of 184,922 patients. The highest three countries that had the most published papers 
in our search were United State (58 papers, 75,456 patients), Italy (23 papers, 15,703 patients), and Germany (21 papers, 11,814 patients). From the 58 papers published in the United States, there were 57 papers on cardiovascular procedures and one paper on noncardiovascular procedures.

\section{Incidence of perioperative stroke}

\section{California state database results}

The 30-day stroke incidence was $0.32 \%(n=11,759)$ in all surgical procedures in this database. The majority of patients suffered from perioperative stroke during the same surgical hospitalization $(86.38 \%, n=10,157)$, while the rest $(13.62 \%, n$ $=1,602$ ) occurred as a readmission within the 30 -day postoperative period after discharge, or as a visit to the ED or as a visit to an observation unit in an outpatient setting.

The incidence of perioperative stroke in the state of California during 2010 to 2011 for each gender according to different age groups and races, as well as the overall incidence through 2008 to 2011 for age and race using the dataset for the state of California and the NIS are shown in Table 1. For incidence calculation and comparison between the two genders in Table 1, OBGYN and male reproductive surgeries were excluded, resulting in 2,537,251 patients in 2008 to 2011. The incidence of perioperative stroke rises significantly after the age of 40 in both genders (Table 1). However, the incidence was markedly higher in patients younger than 17 years old-compared to the following older age groups-in both genders in 2010 to 2011 with an incidence of $0.15 \%(n=196)$ in that age group. Among race groups, perioperative stroke was highest among Asian and Pacific Islander in both genders in 2010 to 2011 with an incidence of $0.45 \%(n=1,181)$.

Surgical procedures with the highest incidence of perioperative strokes in the state of California for different age groups during 2008 to 2011 are shown in Figure 1. It shows that neurosurgical and cardiac procedures have the highest perioperative stroke incidence in age groups between 65 to 95 years old, neurosurgery peaking at $2.19 \%$ in the age group of 86 to 90 years and cardiac surgery peaking at 2.5\% in the age group of 91 to 95 years. Meanwhile, organ transplant procedures were the highest in almost all age groups younger than 65 years, peaking at $4.17 \%$ in the age group of 36 to 40 years. The incidence of perioperative stroke in all surgical procedures peaked at $0.82 \%$ in the age group of 86 to 90 years, while it had an apparent increase starting at the age of 40 .

The incidence of perioperative stroke in the state of California during 2010 to 2011 according to the surgical procedure for each gender, as well as the overall incidence during 2008 to 2011, are shown in Table 2. The surgical categories with the highest overall incidence of perioperative stroke were organ transplant surgeries $1.9 \%(n=74)$ followed by neurosurgeries $1.25 \%(n=1,594)$ and vascular surgeries $1.07 \%(n=3,170)$.

The incidence of perioperative stroke in patients with different comorbidities in the state of California during 2008 to 2011, as

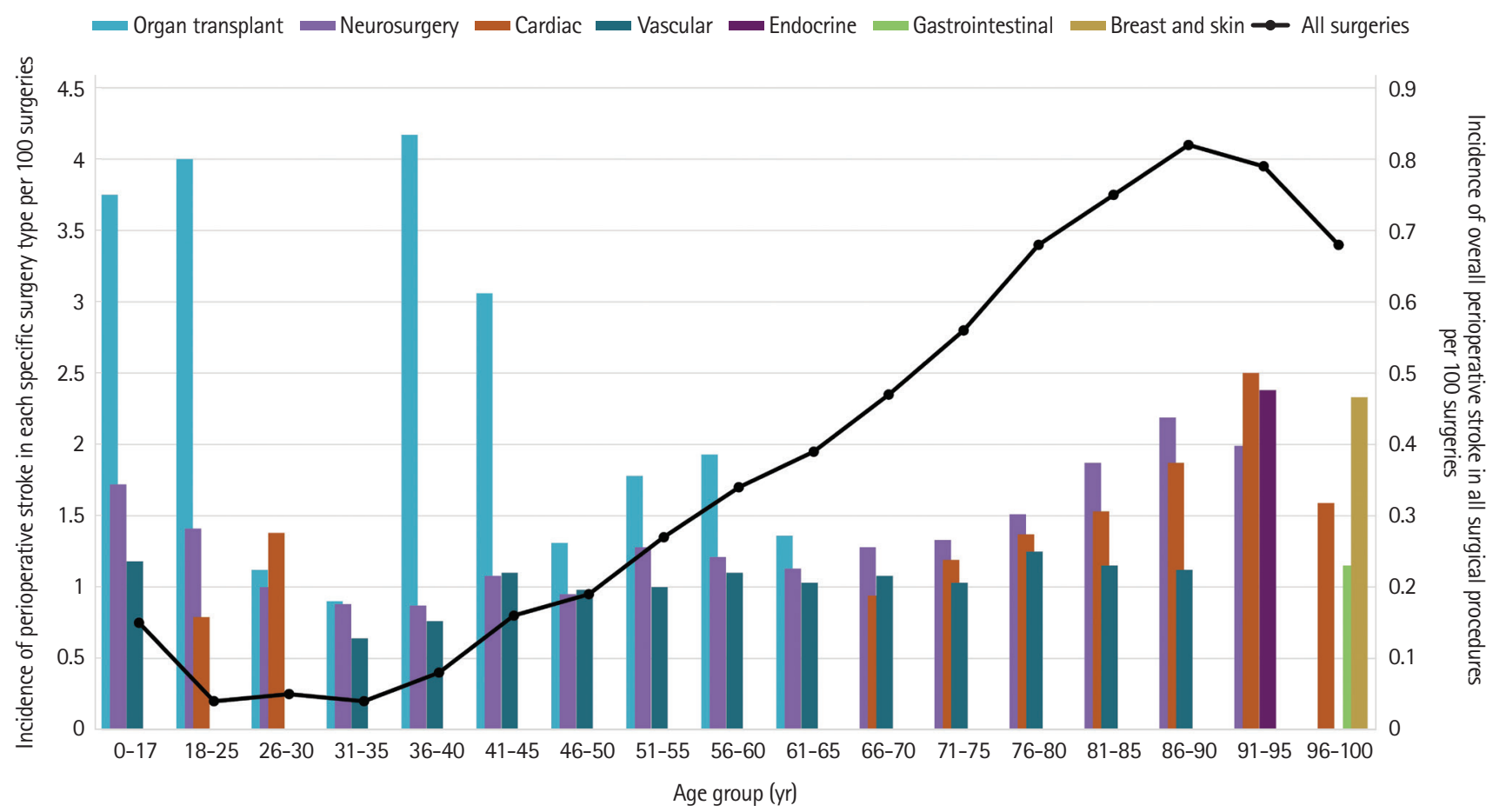

Figure 1. The overall Incidence of perioperative stroke according to different age groups and the highest three surgical categories in each age group. 
Number of comorbidities

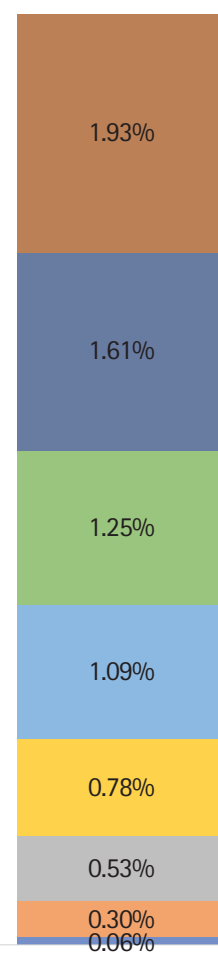

Year 2008

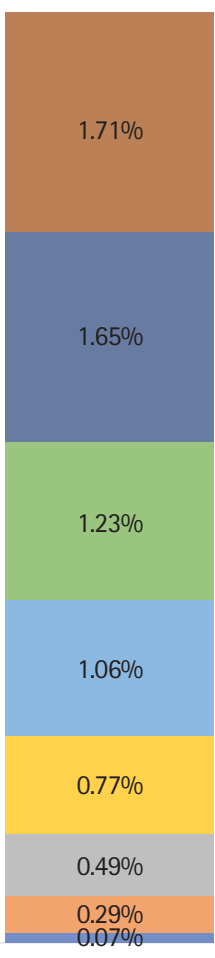

Year 2009

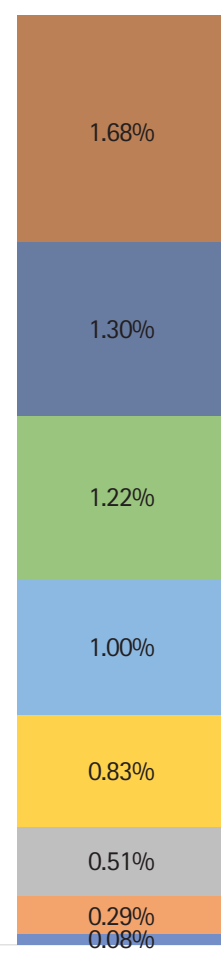

Year 2010

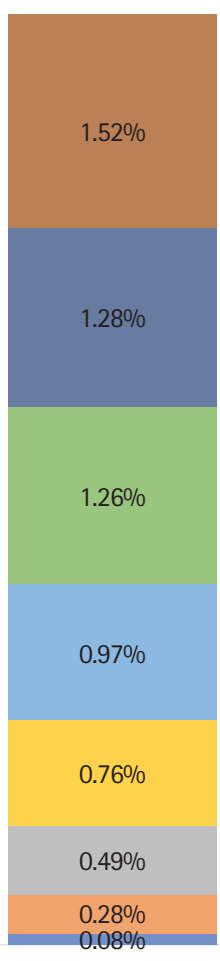

Year 2011

Individual comorbidities

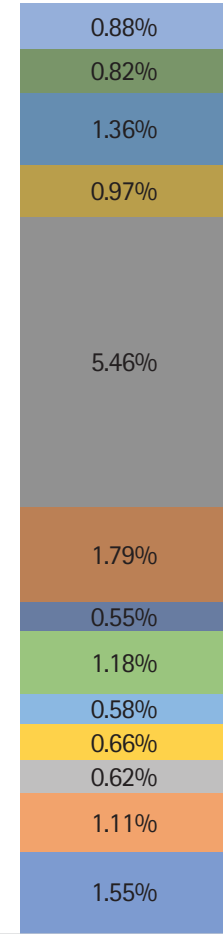

Year 2008

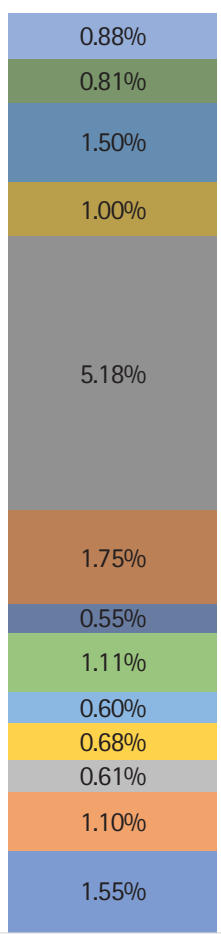

Year 2009

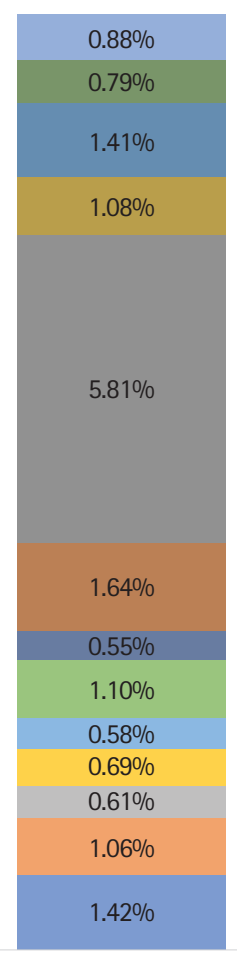

Year 2010

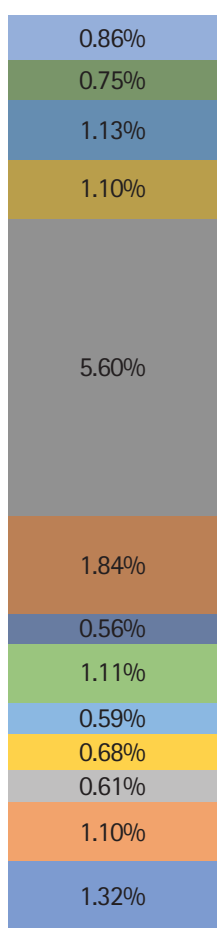

Year 2011

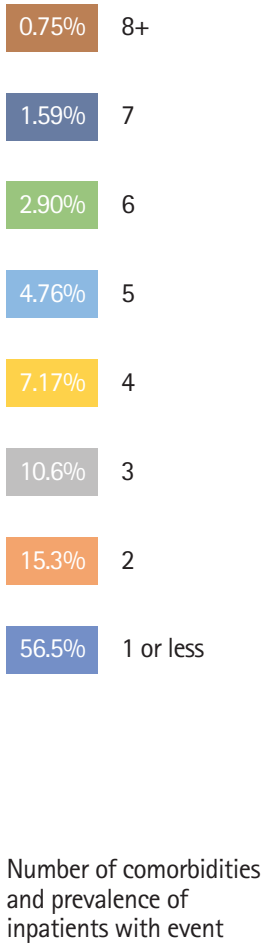

A

Figure 2. Associated comorbidities in patients who suffered from a perioperative stroke in the state of California during 2008 to 2011 . (A) The association between the number of comorbidities and the incidence of perioperative stroke, as well as the prevalence of the count of comorbidities in patients who suffered from a perioperative stroke. (B) The incidence of perioperative stroke with different comorbidities and the prevalence of those comorbidities in patients who suffered from a perioperative stroke. 
well as the prevalence of those comorbidities in patients who suffered from a perioperative stroke, are shown in Figure 2. Correlation between the number of comorbidities and the incidence of perioperative stroke is shown in Figure $2 \mathrm{~A}$, as patients who had increasing numbers of comorbidities, had a higher incidence of perioperative stroke. It also shows that $56.5 \%$ of patients who suffered from perioperative stroke had one comorbidity or less. Specific comorbidities shown in Figure 2B, demonstrate that patients who had paralysis or other neurologic disorders had the highest incidence of perioperative stroke that ranges between $5.18 \%$ to $5.81 \%$ and $1.64 \%$ to $1.84 \%$ respectively. It also shows that hypertension $(68.03 \%, n=8,000)$, fluid and electrolyte disorders $(39.10 \%, n=4,598)$, and paralysis $(29.08 \%, n=3,419)$ were the most prevalent comorbidities in patients who suffered from a perioperative stroke.

\section{NIS database results}

The overall incidence of inpatient perioperative stroke from the NIS is $0.42 \%(n=204,549)$, results from the NIS in Table 1 shows a similar pattern to the California state database with slightly higher incidences in age groups older than 40 . However, the youngest age group ( 0 to 17 years) did not show a significantly higher perioperative stroke incidence compared to the older age groups.

\section{Systematic review}

From our systematic review, 187 articles were qualified for

Table 3. Characteristics of systematic review results according to surgical procedure type

\begin{tabular}{lrrr}
\hline Surgery & $\begin{array}{c}\text { Sample } \\
\text { size }\end{array}$ & $\begin{array}{c}\text { No. of } \\
\text { studies }\end{array}$ & $\begin{array}{r}\text { No. of } \\
\text { strokes }\end{array}$ \\
\hline Non-cardiovascular* & 39,208 & 10 & 233 \\
Cardiovascular & 145,714 & 178 & 2,342 \\
Cardiac surgeries & 78,233 & 82 & 1,555 \\
$\quad$ CABG & 56,414 & 49 & 1,035 \\
Valvular heart surgery & 4,100 & 12 & 86 \\
Surgical ablation for atrial fibrillation & 1,814 & 6 & 14 \\
$\quad$ Other cardiac surgery & 15,905 & 15 & 420 \\
Carotid surgeries & 64,879 & 87 & 756 \\
Carotid artery stenting & 3,984 & 12 & 76 \\
CEA & 59,528 & 70 & 651 \\
Other carotid surgeries & 1,367 & 5 & 22 \\
Aortic surgeries & 787 & 6 & 22 \\
Other peripheral vascular surgeries & 1,815 & 3 & 9 \\
All surgeries & 184,922 & 188 & 2,575 \\
\hline
\end{tabular}

CABG, coronary artery bypass grafting; CEA, carotid endarterectomy. *Detailed list can be found in Supplementary Table 6. data extraction and yielded an overall cohort sample size of 184,922 as shown in Table 3, detailed information about the search results can be found in Supplementary Material and Supplementary Table 6.

Studies that provided information about perioperative strokes occurring in cardiovascular and non-cardiovascular procedures, comprised a cohort of 145,714 and 39,208 patients and the perioperative stroke incidence and stroke number ranged from $0 \%$ to $13.86 \%(n=0-214$; total $=2,342)$ and $0 \%$ to $1.05 \%(n=0-123 ;$ total $=233)$, respectively.

\section{Estimation}

In the state of California during the year 2011, our databases showed that there had been 911,126 surgical procedures performed, and had an incidence of perioperative stroke of $0.33 \%$. Nationally during the same year, the NIS showed that there had been $11,934,162$ surgical procedures performed, and had a $0.46 \%$ incidence of perioperative stroke. Using our databases from the state of California and the NIS, it can be estimated that in any given year there would be approximately 40,000 to 55,000 perioperative strokes nationally, and its incidence would be close to $0.33 \%$ to $0.46 \%$ and that constitutes of approximately $6.25 \%$ of all strokes that happen in the USA every year. ${ }^{12}$

In the state of California during the year 2011 as well, our databases showed that there had been 11,534 CABG and 6,301 carotid endarterectomies (CEAs) performed and had an incidence of perioperative stroke of $1.53 \%$ and $1.56 \%$, respectively. Nationally during the same year, the NIS showed that there had been 163,864 CABG and 98,626 CEA surgeries performed and had an incidence of perioperative stroke of $1.76 \%$ and 3.04\% respectively. In the systematic review performed, studies that reported the incidence of perioperative stroke in $C A B G$ and CEA in the United States ranged from 0\% to 7.69\% in 14 papers (cohort=27,173 patients) and $0 \%$ to $4.16 \%$ in 22 papers (cohort $=32,116)$ respectively. It can be estimated that in any given year, there would be approximately 2,500 to 3,000 and 1,000 to 3000 perioperative strokes nationally that result from $C A B G$ and $C E A$, respectively.

\section{Discussion}

Our study identifies the incidence of perioperative stroke according to the surgical procedure performed as well as gender, age, and race of patients using various databases from the HCUP from 2008 to 2011. A systematic review of the literature was also performed to identify the incidences of perioperative stroke in the United States and other countries published between the years 1980 to 2017. Most perioperative strokes from 
the HCUP in the present study (86.3\%) occurred during the same surgical hospitalization in agreement with other studies that reported the occurrence of perioperative stroke during the first postoperative week. ${ }^{6}$ The NIS database during 2008 to 2011 included 48,672,974 weighted hospitalizations, resulted in an overall incidence of perioperative stroke of $0.42 \%$. Results from the state of California and NIS showed similar results according to the incidence of perioperative stroke. There have been no noticeable trends over the incidence of perioperative stroke during the years our data was obtained from, although the incidence of stroke in the general population has been decreasing over the past 20 years due to improvement in blood pressure control and a decrease in smoking prevalence. ${ }^{13}$

The results reported from the analysis of our data are consistent with other previous studies, which reported that the overall incidence of perioperative stroke in various surgical procedures ranged between $0.2 \%$ and $0.7 \% .{ }^{14-17}$ Female gender and advanced age have been consistently reported as a risk factor for perioperative stroke; as our California population cohort showed that patients who suffered from perioperative stroke were older (67.6 \pm 16.7 years vs. $52.4 \pm 21.1$ years). ${ }^{2,17}$ The overall incidence of perioperative stroke started increasing after the 4th decade significantly (Figure 1). However, the higher incidence of perioperative stroke in the age group of 0 to 17 years can be explained by the increased rates of certain surgical procedures in pediatrics. Congenital defects that involve the heart and central nervous system would put this age group under surgical procedures that have an increased risk for perioperative stroke. ${ }^{18,19}$

Our systematic review showed that the incidence and number of perioperative stroke to be higher in Cardiovascular procedures than non-cardiovascular procedures ranging from $0 \%$ to $13.86 \%$ ( $n=0-214 ; 177$ papers) and $0 \%$ to $1.05 \%$ ( $n=0-$ 123; 10 papers), respectively. In cardiovascular procedures, most literature had a focus on CEA, CABG, and valvular procedures, with no specific trend or change in the incidence of perioperative stroke in the United States in these or any other surgical procedures over time. Somatosensory evoked potential is mainly used in CEAs to detect and diagnose perioperative strokes. ${ }^{20}$ Many studies reported that the incidence of perioperative stroke in procedures like CABG and valvular heart surgeries had higher incidences than carotid surgeries, this could mean that intraoperative monitoring might need to be broadened to include further surgical procedures in order to prevent and manage perioperative strokes.

The different incidences in each surgical procedures can be accounted for various pathophysiologic pathways. Surgical procedures can cause hemodynamic and inflammatory changes that increase the risk of stroke., ${ }^{3,8}$ t has been estimated that embolic events cause more than $60 \%$ of perioperative strokes, followed by unknown causes (13.9\%), a synergistic effect from hypotension, hypoperfusion and formation of microemboli together (10\%), hypoperfusion (9\%), hemorrhagic strokes (1\%), and the remaining 20\% is distributed between other minor and unknown causes. ${ }^{3,6,21}$ Surgery also has been known to amplify the inflammatory pathways which can initiate or exacerbate cerebral ischemic injury., ${ }^{3,9}$ Perioperative hemorrhagic strokes have been linked to sudden surges of cerebral perfusion; revascularization procedures; for example, can lead to cerebral hyperperfusion syndrome that causes acute neurological deficits. ${ }^{21}$ Solid organ transplant surgeries have been previously reported to be associated with different neurological complications; stroke specifically was found to be the most common neurologic complication within the first 30 days after transplant, especially in liver, heart, and lung transplant surgeries. ${ }^{22-24}$ Zierer et al..$^{24}$ explained that there are fundamental factors that contribute to the high incidence of perioperative stroke after heart transplant surgeries, which include prolonged cardiopulmonary bypass and metabolic changes secondary to hepatic failure. Perioperative strokes that occur after neurosurgeries have been linked to local changes and alterations to the physiological regulation of brain vascular circulation, autoregulation, and vasomotricity. These changes vary according to the nature of different tumoral, vascular, infectious or traumatic conditions, different localization, and different surgical technique used in the procedure. ${ }^{25}$

\section{Strengths and limitations}

This study was conducted using claims databases obtained from the HCUP, as they allow the analysis of a large number of patients and facilitates multi-state and national analysis and comparison. A major strength of this study is its large cohort size, with sufficient cases in each sex, age, and race groups to allow generalizability and population analysis. Furthermore, the usage of POA enables us to differentiate between strokes that occurred as a postoperative complication and patients presenting with strokes.

However, some of the limitations of using claims databases from HCUP include that it depends on proper ICD-9 coding for each diagnosis, as well as its inconsistency and overlapping of the codes of specific procedures that could affect the analysis and results. Although the usage of the POA indicator helps us differentiate between strokes that occurred before the time of admission, there is a possibility that some of the strokes might have happened after admission and before the surgical procedure. Furthermore, the lack of POA in the NIS database can attribute to the slightly higher incidences of perioperative stroke 
than in the state of California (Table 1) as some of those strokes may have happened at the time of admission and before surgery. The presence of paralysis and other neurologic disorders as the most prevalent comorbidities (Figure $2 \mathrm{~B}$ ) might also indicate that those patients had these comorbidities from a previous medical condition such as a previous stroke. Some limitations of our systematic review include that the incidence of perioperative stroke may have varied in various studies, which may be caused by different diagnostic protocols for strokes in each hospital or healthcare facility. Comorbidities that increase the risk of perioperative strokes such as hypertension, diabetes, and older age may have been more prevalent in some studies more than others and affected the variance of the systematic review.

\section{Conclusions}

Further prospective studies are needed in surgical procedures with a relatively high incidence of perioperative stroke to identify further strategies and stratify patients at high risk before the surgical procedures to improve patient counseling and a future potential treatment plan. Perioperative stroke is an underrecognized complication that accounts for about $6 \%$ for all strokes that happen in the United States annually.

\section{Supplementary materials}

Supplementary materials related to this article can be found online at https://doi.org/10.5853/jos.2019.00304.

\section{Disclosure}

The authors have no financial conflicts of interest.

\section{References}

1. Sanders RD, Grocott HP. Perioperative stroke: time to redefine the impact of age? Stroke 2012;43:3-5.

2. Vlisides P, Mashour GA. Perioperative stroke. Can J Anaesth 2016;63:193-204.

3. Ng JL, Chan MT, Gelb AW. Perioperative stroke in noncardiac, nonneurosurgical surgery. Anesthesiology 2011;115:879-890.

4. McDonagh DL, Mathew JP. Perioperative stroke: where do we go from here? Anesthesiology 2011;114:1263-1264.

5. Chiao SS. Zuo ZY. Approach to risk management of perioperative stroke. J Anesth Perioper Med 2015;2:268-276.

6. Selim M. Perioperative stroke. N Engl J Med 2007;356:706713.

7. Cheng $H$, Udesh $R$, Mehta A, Thirumala PD. Perioperative strokes after coronary artery bypass grafting with staged carotid endarterectomy: a nationwide perspective. $J$ Clin Anesth 2017;39:25-30.

8. Kikura M, Bateman BT, Tanaka KA. Perioperative ischemic stroke in non-cardiovascular surgery patients. $J$ Anesth 2010; 24:733-738.

9. Dong $\Pi$, Gelb AW. Perioperative stroke remains an underappreciated cause of morbidity and mortality. J Anesth Perioper Med 2014;1:57-59.

10. Garrett G. Present on admission. Where we are now. J AHIMA 2009;80:22-26.

11. Healthcare Cost and Utilization Project (HCUP). Agency for Healthcare Research and Quality. https://www.ahrq.gov/ data/hcup/index.html. 2013. Accessed August 27, 2019.

12. Benjamin EJ, Virani SS, Callaway CW, Chamberlain AM, Chang AR, Cheng $S$, et al. Heart disease and stroke statistics-2018 update: a report from the American Heart Association. Circulation 2018;137:e67-e492.

13. Vangen-Lønne AM, Wilsgaard $T$, Johnsen SH, Løchen ML, Njølstad I, Mathiesen EB. Declining incidence of ischemic stroke: what is the impact of changing risk factors? The Tromsø Study 1995 to 2012. Stroke 2017;48:544-550.

14. Larsen SF, Zaric D, Boysen G. Postoperative cerebrovascular accidents in general surgery. Acta Anaesthesiol Scand 1988; 32:698-701.

15. Kam PC, Calcroft RM. Peri-operative stroke in general surgical patients. Anaesthesia 1997;52:879-883.

16. Knapp RB, Topkins MJ, Artusio JF Jr. The cerebrovascular accident and coronary occlusion in anesthesia. JAMA 1962;182: 332-334.

17. Kaatz S, Douketis JD, Zhou H, Gage BF, White RH. Risk of stroke after surgery in patients with and without chronic atrial fibrillation. J Thromb Haemost 2010;8:884-890.

18. Chen J, Zimmerman RA, Jarvik GP, Nord AS, Clancy RR, Wernovsky $G$, et al. Perioperative stroke in infants undergoing open heart operations for congenital heart disease. Ann Thorac Surg 2009;88:823-829.

19. Ng PY, Ng AK, Subramaniam B, Burns SM, Herisson F, Timm $F P$, et al. Association of preoperatively diagnosed patent foramen ovale with perioperative ischemic stroke. JAMA 2018;319:452-462.

20. Reddy RP, Brahme IS, Karnati T, Balzer JR, Crammond DJ, Anetakis $\mathrm{KM}$, et al. Diagnostic value of somatosensory evoked potential changes during carotid endarterectomy for 30-day perioperative stroke. Clin Neurophysiol 2018;129:1819-1831.

21. Ko SB. Perioperative stroke: pathophysiology and management. Korean J Anesthesiol 2018;71:3-11.

22. Patchell RA. Neurological complications of organ transplan- 
tation. Ann Neurol 1994;36:688-703.

23. Pruitt $A A$, Graus $F$, Rosenfeld MR. Neurological complications of solid organ transplantation. Neurohospitalist 2013;3:152166.

24. Zierer A, Melby SJ, Voeller RK, Guthrie TJ, Al-Dadah AS, Meyers $B F$, et al. Significance of neurologic complications in the modern era of cardiac transplantation. Ann Thorac Surg 2007;83:1684-1690.

25. Landriel F, Ajler P, Yampolsky C. Postoperative stroke in neurosurgery. In: Qureshi Al, Tsiskaridze A, Lindgren A. TreatmentRelated Stroke: Including latrogenic and In-Hospital Strokes. Cambridge, UK: Cambridge University Press, 2016:23-32. 


\section{Supplementary Material}

\section{Search criteria and strategy}

An electronic search of PubMed, Embase, and Web of Science was performed to retrieve published articles related to postoperative $s$ that were published from January 1970 through December 2017. The search was completed by combining keywords for stroke (stroke OR Cerebrovascular accident OR CVA OR Cerebral ischemia OR Brain ischemia) with surgery-specific key terms (postoperative OR perioperative OR post-operative OR peri-operative $O R$ postprocedural $O R$ post-procedural $O R$ postsurgical OR post-surgical OR postoperative care OR postoperative care OR surgical patient OR postoperative complication OR post-operative complication). For Pubmed, the terms (prospective studies[mesh:noexp] OR prospective[TIAB]) were used to specify prospective studies only. The search criteria and inclusion/exclusion criteria were created in a way to minimize bias commonly encountered in observational studies. The Quality Assessment of Diagnostic Accuracy Studies, version 2, was performed to evaluate for bias and to determine whether the chosen studies were relevant to the review question.

\section{Inclusion \& exclusion criteria for study selection}

The inclusion criteria included the following: (1) all prospective studies, (2) incident postoperative stroke that was identified using criteria for the study, (3) studies inclusive of postoperative neurological outcomes within 30 days postoperative, (4) reported quantitative data, (5) studies published in English, (6) studies that included an abstract, and (7) studies done on 100 patients or more.

\section{Data extraction}

Two authors (R.A. and E.J.) independently reviewed all the titles and abstracts of the articles from the electronic search to identify those that satisfied all the inclusion criteria, and a third researcher (K.A.) settled any disagreements. Simultaneously, an Excel spreadsheet was constructed by each author outlining the articles to be excluded-the reason why a study was eliminated was indicated by a number corresponding to the inclusion criteria that was not met. A third author reconciled inclusion/exclusion disagreements and assembled a final list of studies for this review. The following data were extracted from each study: author name and year, sample size, the incidence of perioperative stroke, number of strokes.

\section{Search results}

A search was conducted on December 18, 2017 using the terms mentioned and resulted with total 4,035 references, 870 duplicates were removed from the three databases using endnote, leaving 3,166 potential references. Looking further into the abstracts of the references, 2,830 articles were excluded after title/abstract screening; 484 were not prospective studies, 1,578 the incidence of perioperative stroke and neurologic outcome was not identified within 30 days, 335 had a sample size of fewer than 100 patients, six studies were not performed on humans and 427 were more duplicated studies found, leaving 336 articles.

After full-text screen, 187 articles were qualified for data extraction. The overall sample size is 184,922 patients that had an incidence of perioperative stroke ranging from $0 \%$ to $13.86 \%$. Studies that provided information about perioperative strokes occurring in cardiovascular and non-cardiovascular procedures, comprised of a total cohort of 145,714 and 39,208. The highest three countries that had the most published papers in our search were United State (58 papers; 75,456 patients), Italy (23 papers; 15,703 patients), and Germany (21 papers; 11,814 patients). From the 58 papers published in the United States, there were 57 papers on cardiovascular procedures and one paper on noncardiovascular procedures. 
Supplementary Table 1. Surgical subcategories used and the surgical procedures they include

\begin{tabular}{|c|c|c|}
\hline Surgical subcategory & ICD-9 code & Surgical procedure(s) \\
\hline Ventricular shunt to extracranial site & 0231 & Ventricle to nasopharynx shunt, ventriculomastoid anastomosis \\
\hline Craniotomy and craniectomy; reopening of craniotomy site & 0123 & - \\
\hline Other incision of brain & 0139 & $\begin{array}{l}\text { Amygdalohippocampotomy, drainage of intracerebral hematoma, incision of } \\
\text { brain NOS } \\
\text { Excludes: division of cortical adhesions }\end{array}$ \\
\hline Other craniectomy & 0124 & $\begin{array}{l}\text { Cranial (decompression. exploration, trephination), craniotomy NOS, craniotomy } \\
\text { with removal of (epidural abscess, extradural hematoma, foreign body of skull) } \\
\text { Excludes: removal of foreign body with incision into brain }\end{array}$ \\
\hline Incision of cerebral meninges & 0131 & $\begin{array}{l}\text { Drainage of (intracranial hygroma, subarachnoid abscess (cerebral), subdural } \\
\text { empyema) }\end{array}$ \\
\hline Insertion of implantable heart assist system & 3766 & $\begin{array}{l}\text { Axial flow heart assist system, diagonal pump heart assist system, left ventric- } \\
\text { ular assist device, pulsatile heart assist system, right ventricular assist device, } \\
\text { rotary pump heart assist system, transportable implantable heart assist sys- } \\
\text { tem, ventricular assist device not otherwise specified } \\
\text { Excludes: implant of pulsation balloon, implantation of total internal biventric- } \\
\text { ular heart replacement system (artificial heart), insertion of percutaneous ex- } \\
\text { ternal heart assist device }\end{array}$ \\
\hline Open heart valvuloplasty of aortic valve without replacement & 3511 & - \\
\hline Open and other replacement of aortic valve with tissue graft & 3521 & Repair of aortic valve with tissue graft (autograft, heterograft, homograft) \\
\hline Implant of pulsation balloon & 3761 & - \\
\hline (Aorto)coronary bypass of three coronary arteries & 3613 & - \\
\hline $\begin{array}{l}\text { Endovascular removal of obstruction from head and neck } \\
\text { vessel(s) }\end{array}$ & 3974 & $\begin{array}{l}\text { Endovascular embolectomy, endovascular thrombectomy of pre-cerebral and } \\
\text { cerebral vessels, mechanical embolectomy or thrombectomy } \\
\text { Excludes: endarterectomy of intracranial vessels and other vessels of head and } \\
\text { neck, occlusive endovascular repair of head or neck vessels, open embolecto- } \\
\text { my or thrombectomy }\end{array}$ \\
\hline Extracranial-intracranial vascular bypass & 3928 & - \\
\hline Clipping of aneurysm & 3951 & Excludes: clipping of arteriovenous fistula \\
\hline Endarterectomy; other vessels of head and neck & 3812 & $\begin{array}{l}\text { Extirpation of matter from: right/left common carotid artery, right/left internal } \\
\text { carotid artery, right/left external carotid artery, right/left vertebral artery, facial } \\
\text { artery, right/left temporal artery, right/left thyroid artery }\end{array}$ \\
\hline Percutaneous transluminal coronary angioplasty & 0066 & $\begin{array}{l}\text { Balloon angioplasty of coronary artery, coronary atherectomy, percutaneous } \\
\text { coronary angioplasty NOS }\end{array}$ \\
\hline Heart transplantation & 3751 & - \\
\hline Combined heart-lung transplantation & 336 & - \\
\hline Bilateral lung transplantation & 3352 & Double-lung transplantation, en bloc transplantation \\
\hline Other transplant of liver & 5059 & Exclude: auxiliary hepatic transplantation leaving patient's own liver in situ \\
\hline Pancreatic transplant NOS & 5280 & - \\
\hline Reopening of recent thoracotomy site & 3403 & - \\
\hline Other and unspecified pneumonectomy & 3259 & Excludes: thoracoscopic pneumonectomy \\
\hline Other lobectomy of lung & 3249 & Excludes: thoracoscopic lobectomy of lung \\
\hline Decortication of lung & 3451 & Excludes: thoracoscopic decortication of lung \\
\hline Thoracoscopic excision of lesion or tissue of lung & 3220 & Thoracoscopic wedge resection \\
\hline Partial excision of pituitary gland, transfrontal approach & 0761 & $\begin{array}{l}\text { Cryohypophysectomy, partial transfrontal approach, division of hypophyseal } \\
\text { stalk transfrontal approach, excision of lesion of pituitary (hypophysis) trans- } \\
\text { frontal approach, hypophysectomy subtotal transfrontal approach, infundibu- } \\
\text { lectomy hypophyseal transfrontal approach } \\
\text { Excludes: biopsy of pituitary gland transfrontal approach }\end{array}$ \\
\hline Partial excision of pineal gland & 0753 & Excludes: biopsy of pineal gland \\
\hline Division of thyroid isthmus & 0691 & Transection of thyroid isthmus \\
\hline Unilateral adrenalectomy & 0722 & $\begin{array}{l}\text { Adrenalectomy NOS } \\
\text { Excludes: excision of remaining adrenal gland }\end{array}$ \\
\hline
\end{tabular}


Supplementary Table 1. Continued

\begin{tabular}{|c|c|c|}
\hline Surgical subcategory & ICD-9 code & Surgical procedure(s) \\
\hline Complete thyroidectomy & 064 & Excludes: complete substernal thyroidectomy \\
\hline Open total intra-abdominal colectomy & 4582 & - \\
\hline Open and other left hemicolectomy & 4575 & Excludes: proctosigmoidectomy, second stage Mikulicz operation \\
\hline Exploratory laparotomy & 5411 & Excludes: exploration incidental to intra-abdominal surgery \\
\hline Other partial resection of small intestine & 4562 & $\begin{array}{l}\text { Duodenectomy, ileectomy, jejunectomy } \\
\text { Excludes: duodenectomy with synchronous pancreatectomy, resection of ce- } \\
\text { cum and terminal ileum }\end{array}$ \\
\hline Cholecystectomy & 5122 & Excludes: laparoscopic cholecystectomy \\
\hline Other removal or destruction of corneal lesion & 1149 & $\begin{array}{l}\text { Excision of cornea NOS } \\
\text { Excludes: biopsy of cornea }\end{array}$ \\
\hline Other extracapsular extraction of lens & 1359 & Exclude: extracapsular extraction of lens by temporal inferior route \\
\hline Other repair of retinal detachment & 1459 & $\begin{array}{l}\text { Exclude: repair of retinal detachment with diathermy, cryotherapy, xenon arc pho- } \\
\text { tocoagulation, laser photocoagulation, photocoagulation of unspecified type }\end{array}$ \\
\hline Other operations on vitreous & 1479 & $\begin{array}{l}\text { Exclude: open sky technique, removal of vitreous, anterior approach, aspiration } \\
\text { of vitreous by posterior sclerotomy, mechanical vitrectomy by anterior/poste- } \\
\text { rior approach, injection of vitreous substitute }\end{array}$ \\
\hline Suture of corneal laceration & 1151 & - \\
\hline Total splenectomy & 415 & Splenectomy NOS \\
\hline Radical excision of periaortic lymph nodes & 4052 & - \\
\hline Biopsy of lymphatic structure & 4011 & - \\
\hline Radical neck dissection, unilateral & 4041 & - \\
\hline Excision of axillary lymph node & 4023 & - \\
\hline Amputation above knee & 8417 & $\begin{array}{l}\text { Amputation of leg through femur, amputation of thigh, conversion of below- } \\
\text { knee amputation into above-knee amputation, supracondylar above-knee } \\
\text { amputation }\end{array}$ \\
\hline Atlas-axis spinal fusion & 8101 & $\begin{array}{l}\text { Craniocervical fusion by (anterior, transoral, or posterior technique), C1-C2 fu- } \\
\text { sion by (anterior, transoral, or posterior technique), occiput C2 fusion by (an- } \\
\text { terior, transoral, or posterior technique) }\end{array}$ \\
\hline Other amputation below knee & 8415 & Amputation of leg through tibia and fibula NOS \\
\hline Partial hip replacement & 8152 & Bipolar endoprosthesis \\
\hline Open reduction of fracture with internal fixation; femur & 7935 & Excludes: that for separation of epiphysis \\
\hline Nephroureterectomy & 5551 & $\begin{array}{l}\text { Nephroureterectomy with bladder cuff, total nephrectomy (unilateral) } \\
\text { Excludes: removal of transplanted kidney }\end{array}$ \\
\hline Percutaneous nephrostomy without fragmentation & 5503 & $\begin{array}{l}\text { Nephrostolithotomy (nephroscopic), percutaneous removal of kidney stone(s) } \\
\text { by: (basket extraction, forceps extraction [nephroscopic]), pyelostolithotomy } \\
\text { (nephroscopic), with placement of catheter down ureter } \\
\text { Excludes: percutaneous removal by fragmentation, repeat nephroscopic re- } \\
\text { moval during current episode }\end{array}$ \\
\hline Radical cystectomy & 5771 & $\begin{array}{l}\text { Pelvic exenteration in male, removal of (bladder, prostate, seminal vesicles, and } \\
\text { fat), removal of (bladder, urethra, and fat in a female) } \\
\text { Excludes: that as part of pelvic exenteration in female }\end{array}$ \\
\hline $\begin{array}{l}\text { Other transurethral excision or destruction of lesion or tissue } \\
\text { of bladder }\end{array}$ & 5749 & $\begin{array}{l}\text { Endoscopic resection of bladder lesion } \\
\text { Excludes: transurethral biopsy of bladder, transurethral fistulectomy }\end{array}$ \\
\hline Control of (postoperative) hemorrhage of bladder & 5793 & - \\
\hline Other transurethral prostatectomy & 6029 & $\begin{array}{l}\text { Excision of median bar by transurethral approach, transurethral electrovapor- } \\
\text { ization of prostrate, transurethral enucleative procedure, transurethral pros- } \\
\text { tatectomy NOS, transurethral resection of prostate }\end{array}$ \\
\hline Control of (postoperative) hemorrhage of prostate & 6094 & Coagulation of prostatic bed, cystoscopy for control of prostatic hemorrhage \\
\hline Radical prostatectomy & 605 & $\begin{array}{l}\text { Prostatovesiculectomy, radical prostatectomy by any approach } \\
\text { Excludes: cystoprostatectomy }\end{array}$ \\
\hline Unilateral orchiectomy & 623 & Orchidectomy (with epididymectomy) NOS \\
\hline
\end{tabular}


Supplementary Table 1. Continued

\begin{tabular}{|c|c|c|}
\hline Surgical subcategory & ICD-9 code & Surgical procedure(s) \\
\hline Removal of both testes at same operative episode & 6241 & Bilateral orchidectomy NOS \\
\hline Low cervical cesarean section & 741 & Lower uterine segment cesarean section \\
\hline Other and unspecified total abdominal hysterectomy & 6849 & - \\
\hline $\begin{array}{l}\text { Other removal of both ovaries and tubes at same operative ep- } \\
\text { isode }\end{array}$ & 6561 & Excludes: that by laparoscope \\
\hline Laparoscopic total abdominal hysterectomy & 6841 & Total laparoscopic hysterectomy \\
\hline Classical cesarean section & 740 & Transperitoneal classical cesarean section \\
\hline Fat graft of skin and subcutaneous tissue & 8687 & $\begin{array}{l}\text { Replacement of subcutaneous tissue and fascia for (scalp, face, neck, chest, } \\
\text { back, buttock, abdomen, perineum, pelvic region, arms, hands, legs, feet) with } \\
\text { autologous tissue substitute percutaneous approach, extraction of subcuta- } \\
\text { neous tissue and fascia for (scalp, face, neck, chest, back, buttock, abdomen, } \\
\text { perineum, pelvic region, arms, hands, legs, feet) percutaneous approach }\end{array}$ \\
\hline Bilateral simple mastectomy & 8542 & Bilateral complete mastectomy \\
\hline Removal of implant of breast & 8594 & - \\
\hline Other free skin graft to other sites & 8669 & Excludes: heterograft, homograft \\
\hline Homograft to skin & 8666 & Graft to skin of amnionic membrane from donor skin from donor \\
\hline Sphenoidectomy & 2264 & - \\
\hline Incision of multiple nasal sinuses & 2253 & - \\
\hline Sphenoidotomy & 2252 & - \\
\hline Control of epistaxis by ligation of ethmoidal arteries & 2104 & - \\
\hline Ethmoidectomy & 2263 & - \\
\hline
\end{tabular}

ICD-9, International Classification of Diseases, 9th revision; NOS, not otherwise specified. 
Supplementary Table 2. 100 surgeries that were most frequently performed

\begin{tabular}{|c|c|c|c|c|}
\hline Procedure name & ICD-9 code & Procedure frequency & No. of stroke & Incidence of stroke $(\%)$ \\
\hline Low cervical cesarean section & 741 & 516,134 & 41 & 0.01 \\
\hline Total knee replacement & 8154 & 191,443 & 173 & 0.09 \\
\hline Percutaneous transluminal coronary angioplasty & 0066 & 165,698 & 761 & 0.46 \\
\hline Laparoscopic cholecystectomy & 5123 & 141,814 & 117 & 0.08 \\
\hline Hemodialysis & 3995 & 115,663 & 454 & 0.39 \\
\hline Total hip replacement & 8151 & 98,769 & 111 & 0.11 \\
\hline Laparoscopic appendectomy & 4701 & 92,255 & 22 & 0.02 \\
\hline Other and unspecified total abdominal hysterectomy & 6849 & 691,39 & 27 & 0.04 \\
\hline Open reduction of fracture with internal fixation; femur & 7935 & 51,207 & 275 & 0.54 \\
\hline Percutaneous abdominal drainage & 5491 & 46,708 & 93 & 0.2 \\
\hline Episiotomy & 736 & 45,878 & * & 0.01 \\
\hline Thoracentesis & 3491 & 45,733 & 175 & 0.38 \\
\hline Other cervical fusion of the anterior column, anterior technique & 8102 & 41,651 & 45 & 0.11 \\
\hline Open reduction of fracture with internal fixation; tibia and fibula & 7936 & 41,571 & 42 & 0.1 \\
\hline Other exploration and decompression of spinal canal & 0309 & 37,627 & 77 & 0.2 \\
\hline Excision of intervertebral disc & 8051 & 37,514 & 18 & 0.05 \\
\hline Partial hip replacement & 8152 & 36,879 & 250 & 0.68 \\
\hline Other and unspecified vaginal hysterectomy & 6859 & 33,798 & * & 0.02 \\
\hline Angioplasty of other non-coronary vessel(s) & 3950 & 32,919 & 157 & 0.48 \\
\hline Other appendectomy & 4709 & 32,117 & 13 & 0.04 \\
\hline Lumbar and lumbosacral fusion of the anterior column, posterior technique & 8108 & 31,922 & 53 & 0.17 \\
\hline Radical prostatectomy & 605 & 27,682 & 12 & 0.04 \\
\hline Endarterectomy; other vessels of head and neck & 3812 & 27,172 & 433 & 1.59 \\
\hline Other transurethral prostatectomy & 6029 & 25,617 & 33 & 0.13 \\
\hline Interruption of the vena cava & 387 & 22,439 & 288 & 1.28 \\
\hline Closed reduction of fracture with internal fixation; femur & 7915 & 22,214 & 114 & 0.51 \\
\hline Laparoscopically assisted vaginal hysterectomy & 6851 & 20,672 & * & 0.01 \\
\hline Excision or destruction of other lesion or tissue of heart, endovascular approach & 3734 & 20,145 & 62 & 0.31 \\
\hline Open and other right hemicolectomy & 4573 & 20,075 & 117 & 0.58 \\
\hline Other partial resection of small intestine & 4562 & 19,867 & 121 & 0.61 \\
\hline Lumbar and lumbosacral fusion of the anterior column, anterior technique & 8106 & 18,861 & 23 & 0.12 \\
\hline Other lysis of peritoneal adhesions & 5459 & 18,711 & 48 & 0.26 \\
\hline Open and other sigmoidectomy & 4576 & 18,441 & 90 & 0.49 \\
\hline Cholecystectomy & 5122 & 17,557 & 57 & 0.32 \\
\hline Nephroureterectomy & 5551 & 16,516 & 45 & 0.27 \\
\hline Insertion of intercostal catheter for drainage & 3404 & 16,069 & 52 & 0.32 \\
\hline Open and other replacement of aortic valve with tissue graft & 3521 & 15,928 & 416 & 2.61 \\
\hline Complete thyroidectomy & 064 & 15,238 & * & 0.04 \\
\hline Circumcision & 640 & 15,138 & * & 0.01 \\
\hline Amputation of toe & 8411 & 15,130 & 29 & 0.19 \\
\hline (Aorto)coronary bypass of two coronary arteries & 3612 & 14,793 & 216 & 1.46 \\
\hline Other and unspecified subtotal abdominal hysterectomy & 6839 & 14,602 & * & 0.01 \\
\hline Other excision or destruction of lesion or tissue of brain & 0159 & 14,476 & 468 & 3.23 \\
\hline Lumbar and lumbosacral fusion of the posterior column, posterior technique & 8107 & 14,067 & 29 & 0.21 \\
\hline
\end{tabular}


Supplementary Table 2. Continued

\begin{tabular}{|c|c|c|c|c|}
\hline Procedure name & ICD-9 code & Procedure frequency & No. of stroke & Incidence of stroke $(\%)$ \\
\hline Open reduction of fracture with internal fixation; radius and ulna & 7932 & 13,718 & 10 & 0.07 \\
\hline (Aorto)coronary bypass of three coronary arteries & 3613 & 13,380 & 238 & 1.78 \\
\hline Other open incisional hernia repair with graft or prosthesis & 5361 & 13,063 & * & 0.04 \\
\hline Laparoscopic total abdominal hysterectomy & 6841 & 12,607 & * & 0.03 \\
\hline Open reduction of fracture with internal fixation; humerus & 7931 & 12,565 & 10 & 0.08 \\
\hline Other (peripheral) vascular shunt or bypass & 3929 & 12,302 & 57 & 0.46 \\
\hline Unilateral extended simple mastectomy & 8543 & 12,087 & * & 0.02 \\
\hline Arteriovenostomy for renal dialysis & 3927 & 11,559 & 70 & 0.61 \\
\hline Transurethral removal of obstruction from ureter and renal pelvis & 560 & 11,027 & 10 & 0.09 \\
\hline Incision of cerebral meninges & 0131 & 10,929 & 357 & 3.27 \\
\hline Biopsy of lymphatic structure & 4011 & 10,455 & 36 & 0.34 \\
\hline Internal fixation of bone without fracture reduction; femur & 7855 & 10,171 & 40 & 0.39 \\
\hline Other transurethral excision or destruction of lesion or tissue of bladder & 5749 & 10,151 & 28 & 0.28 \\
\hline Laparoscopic right hemicolectomy & 1733 & 10,009 & 24 & 0.24 \\
\hline Percutaneous nephrostomy without fragmentation & 5503 & 9,998 & 41 & 0.41 \\
\hline Laparoscopic lysis of peritoneal adhesions & 5451 & 9,655 & 11 & 0.11 \\
\hline Arthroplasty; other total shoulder replacement & 8180 & 9,130 & 11 & 0.12 \\
\hline Other amputation below knee & 8415 & 8,776 & 66 & 0.75 \\
\hline Unilateral thyroid lobectomy & 062 & 8,775 & * & 0 \\
\hline Open and other replacement of aortic valve & 3522 & 8,633 & 205 & 2.37 \\
\hline Open and other partial gastrectomy & 4389 & 8,582 & * & 0.08 \\
\hline Excision of axillary lymph node & 4023 & 8,537 & * & 0.02 \\
\hline Laparoscopic sigmoidectomy & 1736 & 8,432 & 12 & 0.14 \\
\hline Endovascular implantation of other graft in abdominal aorta & 3971 & 8,414 & 37 & 0.44 \\
\hline Thoracoscopic excision of lesion or tissue of lung & 3220 & 8,401 & 31 & 0.37 \\
\hline Revision of hip replacement, both acetabular and femoral components & 0070 & 7,814 & 21 & 0.27 \\
\hline Excision of lesion of other soft tissue & 8339 & 7,457 & 13 & 0.17 \\
\hline Other free skin graft to other sites & 8669 & 7,308 & 15 & 0.21 \\
\hline Dorsal and dorsolumbar fusion of the posterior column, posterior technique & 8105 & 7,204 & 18 & 0.25 \\
\hline Other unilateral salpingo-oophorectomy & 6549 & 7,105 & * & 0.01 \\
\hline Other kidney transplantation & 5569 & 7,093 & * & 0.13 \\
\hline Revision of knee replacement, total (all components) & 0080 & 6,983 & * & 0.11 \\
\hline (Aorto)coronary bypass of four or more coronary arteries & 3614 & 6,942 & 134 & 1.93 \\
\hline Implant of pulsation balloon & 3761 & 6,913 & 151 & 2.18 \\
\hline Open and other left hemicolectomy & 4575 & 6,733 & 56 & 0.83 \\
\hline Other removal of both ovaries and tubes at same operative episode & 6561 & 6,644 & * & 0.11 \\
\hline Other endovascular procedures on other vessels & 3979 & 6,577 & 76 & 1.16 \\
\hline Other lobectomy of lung & 3249 & 6,539 & 37 & 0.57 \\
\hline Other revision of vascular procedure & 3949 & 6,309 & 35 & 0.55 \\
\hline Other repair of urinary stress incontinence & 5979 & 6,230 & * & 0.03 \\
\hline Arthroplasty; partial shoulder replacement & 8181 & 6,110 & * & 0.08 \\
\hline (Aorto)coronary bypass of one coronary artery & 3611 & 6,108 & 79 & 1.29 \\
\hline Other cervical fusion of the posterior column, posterior technique & 8103 & 5,539 & 20 & 0.36 \\
\hline Incision of perirectal tissue & 4881 & 5,520 & * & 0.04 \\
\hline
\end{tabular}


Supplementary Table 2. Continued

\begin{tabular}{|c|c|c|c|c|}
\hline Procedure name & ICD-9 code & Procedure frequency & No. of stroke & Incidence of stroke (\%) \\
\hline Other anterior resection of rectum & 4863 & 5,506 & 15 & 0.27 \\
\hline Other myectomy & 8345 & 5,416 & 21 & 0.39 \\
\hline Unilateral simple mastectomy & 8541 & 5,286 & * & 0.02 \\
\hline Single internal mammary-coronary artery bypass & 3615 & 5,282 & 69 & 1.31 \\
\hline Attachment of pedicle or flap graft to other sites & 8674 & 5,254 & * & 0.11 \\
\hline Partial nephrectomy & 554 & 5,180 & * & 0.15 \\
\hline Other and unspecified hysterectomy & 689 & 5,129 & * & 0.06 \\
\hline Amputation above knee & 8417 & 5,021 & 53 & 1.06 \\
\hline Percutaneous vertebral augmentation & 8166 & 4,749 & * & 0.19 \\
\hline Laparoscopy & 5421 & 4,724 & * & 0.11 \\
\hline Amputation through foot & 8412 & 4,686 & 20 & 0.43 \\
\hline Open heart valvuloplasty of mitral valve without replacement & 3512 & 4,597 & 79 & 1.72 \\
\hline
\end{tabular}

ICD-9, International Classification of Diseases, 9th revision.

*Any results showing numbers less than 10 patients to maintain patient privacy. 
Supplementary Table 3. One hundred surgeries that had the highest number of strokes

\begin{tabular}{|c|c|c|c|c|}
\hline Procedure name & ICD-9 code & No. of stroke & Procedure frequency & Incidence of stroke (\%) \\
\hline Percutaneous transluminal coronary angioplasty & 0066 & 761 & 165,698 & 0.46 \\
\hline Other excision or destruction of lesion or tissue of brain & 0159 & 468 & 14,476 & 3.23 \\
\hline Hemodialysis & 3995 & 454 & 115,663 & 0.39 \\
\hline Endarterectomy; other vessels of head and neck & 3812 & 433 & 27,172 & 1.59 \\
\hline Open and other replacement of aortic valve with tissue graft & 3521 & 416 & 15,928 & 2.61 \\
\hline Incision of cerebral meninges & 0131 & 357 & 10,929 & 3.27 \\
\hline Clipping of aneurysm & 3951 & 294 & 2,856 & 10.29 \\
\hline Interruption of the vena cava & 387 & 288 & 22,439 & 1.28 \\
\hline Open reduction of fracture with internal fixation; femur & 7935 & 275 & 51,207 & 0.54 \\
\hline Endovascular (total) embolization or occlusion of head and neck vessels & 3972 & 252 & 4,174 & 6.4 \\
\hline Partial hip replacement & 8152 & 250 & 36,879 & 0.68 \\
\hline (Aorto)coronary bypass of three coronary arteries & 3613 & 238 & 13,380 & 1.78 \\
\hline (Aorto)coronary bypass of two coronary arteries & 3612 & 216 & 14,793 & 1.46 \\
\hline Open and other replacement of aortic valve & 3522 & 205 & 8,633 & 2.37 \\
\hline Excision of lesion or tissue of cerebral meninges & 0151 & 193 & 4,549 & 4.24 \\
\hline Thoracentesis & 3491 & 175 & 45,733 & 0.38 \\
\hline Total knee replacement & 8154 & 173 & 191,443 & 0.09 \\
\hline Endovascular removal of obstruction from head and neck vessel(s) & 3974 & 171 & 926 & 18.47 \\
\hline Angioplasty of other non-coronary vessel(s) & 3950 & 157 & 32,919 & 0.48 \\
\hline Implant of pulsation balloon & 3761 & 151 & 6,913 & 2.18 \\
\hline Other incision of brain & 0139 & 138 & 2,628 & 5.25 \\
\hline (Aorto)coronary bypass of four or more coronary arteries & 3614 & 134 & 6,942 & 1.93 \\
\hline Other partial resection of small intestine & 4562 & 121 & 19,867 & 0.61 \\
\hline Laparoscopic cholecystectomy & 5123 & 117 & 141,814 & 0.08 \\
\hline Open and other right hemicolectomy & 4573 & 117 & 20,075 & 0.58 \\
\hline Closed reduction of fracture with internal fixation; femur & 7915 & 114 & 22,214 & 0.51 \\
\hline Total hip replacement & 8151 & 111 & 98,769 & 0.11 \\
\hline Percutaneous angioplasty of extracranial vessel(s) & 0061 & 110 & 4,312 & 2.55 \\
\hline Other craniotomy & 124 & 104 & 3,030 & 3.43 \\
\hline Resection of vessel with replacement; thoracic vessels & 3845 & 98 & 1,499 & 6.54 \\
\hline Open and other replacement of mitral valve with tissue graft & 3523 & 95 & 2,783 & 3.41 \\
\hline Percutaneous abdominal drainage & 5491 & 93 & 46,708 & 0.2 \\
\hline $\begin{array}{l}\text { Endovascular embolization or occlusion of vessel(s) of head or neck using } \\
\text { bare coils }\end{array}$ & 3975 & 91 & 1,166 & 7.8 \\
\hline Open and other sigmoidectomy & 4576 & 90 & 18,441 & 0.49 \\
\hline (Aorto)coronary bypass of one coronary artery & 3611 & 79 & 6,108 & 1.29 \\
\hline Open heart valvuloplasty of mitral valve without replacement & 3512 & 79 & 4,597 & 1.72 \\
\hline Other exploration and decompression of spinal canal & 0309 & 77 & 37,627 & 0.2 \\
\hline Other endovascular procedures on other vessels & 3979 & 76 & 6,577 & 1.16 \\
\hline Arteriovenostomy for renal dialysis & 3927 & 70 & 11,559 & 0.61 \\
\hline Single internal mammary-coronary artery bypass & 3615 & 69 & 5,282 & 1.31 \\
\hline Other amputation below knee & 8415 & 66 & 8,776 & 0.75 \\
\hline Open and other replacement of mitral valve & 3524 & 64 & 2,639 & 2.43 \\
\hline
\end{tabular}


Supplementary Table 3. Continued

\begin{tabular}{|c|c|c|c|c|}
\hline Procedure name & ICD-9 code & No. of stroke & Procedure frequency & Incidence of stroke (\%) \\
\hline $\begin{array}{l}\text { Excision or destruction of other lesion or tissue of heart, endovascular ap- } \\
\text { proach }\end{array}$ & 3734 & 62 & 20,145 & 0.31 \\
\hline Extracranial-intracranial vascular bypass & 3928 & 60 & 434 & 13.82 \\
\hline Ventricular shunt to abdominal cavity and organs & 234 & 59 & 4,201 & 1.4 \\
\hline Cholecystectomy & 5122 & 57 & 17,557 & 0.32 \\
\hline Other (peripheral) vascular shunt or bypass & 3929 & 57 & 12,302 & 0.46 \\
\hline Open and other left hemicolectomy & 4575 & 56 & 6,733 & 0.83 \\
\hline Lumbar and lumbosacral fusion of the anterior column, posterior technique & 8108 & 53 & 31,922 & 0.17 \\
\hline Amputation above knee & 8417 & 53 & 5,021 & 1.06 \\
\hline Insertion of intercostal catheter for drainage & 3404 & 52 & 16,069 & 0.32 \\
\hline Other lysis of peritoneal adhesions & 5459 & 48 & 18,711 & 0.26 \\
\hline Other craniectomy & 0125 & 46 & 1,008 & 4.56 \\
\hline Other cervical fusion of the anterior column, anterior technique & 8102 & 45 & 41,651 & 0.11 \\
\hline Nephroureterectomy & 5551 & 45 & 16,516 & 0.27 \\
\hline Endovascular implantation of graft in thoracic aorta & 3973 & 45 & 1,216 & 3.7 \\
\hline Open reduction of fracture with internal fixation; tibia and fibula & 7936 & 42 & 41,571 & 0.1 \\
\hline Resection of vessel with replacement; aorta, abdominal & 3844 & 42 & 2,570 & 1.63 \\
\hline Low cervical cesarean section & 741 & 41 & 516,134 & 0.01 \\
\hline Percutaneous nephrostomy without fragmentation & 5503 & 41 & 9,998 & 0.41 \\
\hline Internal fixation of bone without fracture reduction; femur & 7855 & 40 & 10,171 & 0.39 \\
\hline Incision of vessel; lower limb arteries & 3808 & 39 & 1,783 & 2.19 \\
\hline Endovascular implantation of other graft in abdominal aorta & 3971 & 37 & 8,414 & 0.44 \\
\hline Other lobectomy of lung & 3249 & 37 & 6,539 & 0.57 \\
\hline Biopsy of lymphatic structure & 4011 & 36 & 10,455 & 0.34 \\
\hline Other revision of vascular procedure & 3949 & 35 & 6,309 & 0.55 \\
\hline Replacement of ventricular shunt & 0242 & 35 & 3,278 & 1.07 \\
\hline Extracorporeal membrane oxygenation & 3965 & 34 & 389 & 8.74 \\
\hline Other transurethral prostatectomy & 6029 & 33 & 25,617 & 0.13 \\
\hline Annuloplasty & 3533 & 32 & 1,465 & 2.18 \\
\hline Thoracoscopic excision of lesion or tissue of lung & 3220 & 31 & 8,401 & 0.37 \\
\hline Pericardiotomy & 3712 & 31 & 3,094 & 1 \\
\hline Other transplant of liver & 5059 & 31 & 2,095 & 1.48 \\
\hline Incision of vessel; upper limb vessels & 3803 & 31 & 942 & 3.29 \\
\hline Heart transplantation & 3751 & 31 & 882 & 3.51 \\
\hline Open heart valvuloplasty of aortic valve without replacement & 3511 & 31 & 735 & 4.22 \\
\hline Percutaneous angioplasty of intracranial vessel(s) & 0062 & 31 & 359 & 8.64 \\
\hline Partial excision of pituitary gland, transsphenoidal approach & 0762 & 30 & 3,337 & 0.9 \\
\hline Amputation of toe & 8411 & 29 & 15,130 & 0.19 \\
\hline Lumbar and lumbosacral fusion of the posterior column, posterior technique & 8107 & 29 & 14,067 & 0.21 \\
\hline Other transurethral excision or destruction of lesion or tissue of bladder & 5749 & 28 & 10,151 & 0.28 \\
\hline Exploratory laparotomy & 5411 & 28 & 4,374 & 0.64 \\
\hline Aorta-iliac-femoral bypass & 3925 & 28 & 2,399 & 1.17 \\
\hline Excision or destruction of other lesion or tissue of heart, open approach & 3733 & 28 & 1,529 & 1.83 \\
\hline Other and unspecified total abdominal hysterectomy & 6849 & 27 & 69,139 & 0.04 \\
\hline
\end{tabular}


Supplementary Table 3. Continued

\begin{tabular}{lcccc}
\hline Procedure name & ICD-9 code & No. of stroke & Procedure frequency & Incidence of stroke (\%) \\
\hline Insertion of implantable heart assist system & 3766 & 27 & 474 & 5.7 \\
Partial excision of pituitary gland, transfrontal approach & 0761 & 25 & 246 & 10.16 \\
Laparoscopic right hemicolectomy & 1733 & 24 & 1,581 & 0.24 \\
Other repair of aneurysm & 3952 & 24 & 18,861 & 4.52 \\
Lumbar and lumbosacral fusion of the anterior column, anterior technique & 8106 & 23 & 4,123 & 0.12 \\
Total splenectomy & 415 & 23 & 1,095 & 0.56 \\
Percutaneous balloon valvuloplasty & 3596 & 23 & 585 & 2.1 \\
Lobectomy of brain & 0153 & 23 & 407 & 3.93 \\
Ventricular shunt to extracranial site NEC & 239 & 23 & 92,255 & 5.65 \\
Laparoscopic appendectomy & 4701 & 22 & 7,814 & 0.02 \\
Revision of hip replacement, both acetabular and femoral components & 0070 & 21 & 5,416 & 0.27 \\
Other myectomy & 8345 & 21 & 4,469 & 0.39 \\
Revision of arteriovenous shunt for renal dialysis & 3942 & 21 & 5,539 & 0.47 \\
Other cervical fusion of the posterior column, posterior technique & 8103 & 20 & 4,686 & 0.36 \\
Amputation through foot & 8412 & 20 & 0.43
\end{tabular}

ICD-9, International Classification of Diseases, 9th revision; NEC, not otherwise specified. 
Supplementary Table 4. One hundred surgeries that had the highest incidence of perioperative stroke, with procedure frequency $\geq 10$

\begin{tabular}{|c|c|c|c|}
\hline Procedure name & ICD-9 code & Incidence of stroke (\%) & Procedure frequency \\
\hline Implantation or insertion of biventricular external heart assist system & 3760 & 20 & 15 \\
\hline Endovascular removal of obstruction from head and neck vessel(s) & 3974 & 18.47 & 926 \\
\hline Incision of vessel; intracranial vessels & 3801 & 18.18 & 11 \\
\hline Other excision of vessel; intracranial vessels & 3861 & 17.5 & 40 \\
\hline Percutaneous insertion of intracranial vascular stent(s) & 0065 & 16.67 & 12 \\
\hline Extracranial-intracranial vascular bypass & 3928 & 13.82 & 434 \\
\hline Lobotomy and tractotomy & 132 & 11.43 & 35 \\
\hline Clipping of aneurysm & 3951 & 10.29 & 2,856 \\
\hline Partial excision of pituitary gland, transfrontal approach & 0761 & 10.16 & 246 \\
\hline Other removal or destruction of corneal lesion & 1149 & 9.9 & 11 \\
\hline Extracorporeal membrane oxygenation & 3965 & 8.74 & 389 \\
\hline Percutaneous angioplasty of intracranial vessel(s) & 0062 & 8.64 & 359 \\
\hline Incision of vessel; abdominal veins & 3807 & 8 & 25 \\
\hline Endovascular embolization or occlusion of vessel(s) of head or neck using bare coils & 3975 & 7.8 & 1,166 \\
\hline Partial excision of pituitary gland, unspecified approach & 0763 & 7.55 & 53 \\
\hline Resection of vessel with anastomosis; intracranial vessels & 3831 & 7.14 & 28 \\
\hline Other operations on pancreas & 5299 & 6.67 & 15 \\
\hline Excision of uvula & 2772 & 6.67 & 15 \\
\hline Insertion of temporary non-implantable extracorporeal circulatory assist device & 3762 & 6.6 & 33 \\
\hline Resection of vessel with replacement; thoracic vessels & 3845 & 6.54 & 1,499 \\
\hline Endovascular (total) embolization or occlusion of head and neck vessels & 3972 & 6.4 & 4,174 \\
\hline Adjunct vascular system; procedure on single vessel & 0040 & 6.25 & 32 \\
\hline Insertion of percutaneous external heart assist device & 3764 & 6.25 & 16 \\
\hline Incision of vessel; aorta & 3804 & 6.15 & 65 \\
\hline Endovascular embolization or occlusion of vessel(s) of head or neck using bioactive coils & 3976 & 5.9 & 305 \\
\hline Insertion of implantable heart assist system & 3766 & 5.7 & 474 \\
\hline Ventricular shunt to extracranial site NEC & 0239 & 5.65 & 407 \\
\hline Transapical replacement of aortic valve & 3506 & 5.56 & 18 \\
\hline Craniotomy and craniectomy; reopening of craniotomy site & 0123 & 5.49 & 328 \\
\hline Excision, destruction, or exclusion of left atrial appendage & 3736 & 5.41 & 37 \\
\hline Other incision of brain & 0139 & 5.25 & 2,628 \\
\hline Incision of vessel; other thoracic vessels & 3805 & 4.9 & 102 \\
\hline Total excision of pituitary gland, transfrontal approach & 0764 & 4.76 & 21 \\
\hline Other craniectomy & 0125 & 4.56 & 1,008 \\
\hline Sphenoidectomy & 2264 & 4.37 & 183 \\
\hline Other excision of vessel; other thoracic vessels & 3865 & 4.35 & 23 \\
\hline Incision of multiple nasal sinuses & 2253 & 4.35 & 23 \\
\hline Excision of lesion or tissue of cerebral meninges & 0151 & 4.24 & 4,549 \\
\hline Open heart valvuloplasty of aortic valve without replacement & 3511 & 4.22 & 735 \\
\hline Other extracapsular extraction of lens & 1359 & 4.17 & 24 \\
\hline Aorta-subclavian-carotid bypass & 3922 & 4.12 & 437 \\
\hline Lobectomy of brain & 0153 & 3.93 & 585 \\
\hline Division of thyroid isthmus & 0691 & 3.77 & 53 \\
\hline Cardiotomy & 3711 & 3.74 & 107 \\
\hline
\end{tabular}


Supplementary Table 4. Continued

\begin{tabular}{|c|c|c|c|}
\hline Procedure name & ICD-9 code & Incidence of stroke (\%) & Procedure frequency \\
\hline Endovascular implantation of graft in thoracic aorta & 3973 & 3.7 & 1,216 \\
\hline Placement of intracerebral catheter(s) via burr hole(s) & 0128 & 3.63 & 248 \\
\hline Heart transplantation & 3751 & 3.51 & 882 \\
\hline Other intra-abdominal vascular shunt or bypass & 3926 & 3.49 & 172 \\
\hline Intraoperative cardiac pacemaker & 3964 & 3.45 & 29 \\
\hline Other craniotomy & 0124 & 3.43 & 3,030 \\
\hline Open and other replacement of mitral valve with tissue graft & 3523 & 3.41 & 2,783 \\
\hline Sphenoidotomy & 2252 & 3.31 & 121 \\
\hline Combined heart-lung transplantation & 336 & 3.3 & 33 \\
\hline Incision of vessel; upper limb vessels & 3803 & 3.29 & 942 \\
\hline Operations on carotid body, carotid sinus and other vascular bodies & 398 & 3.28 & 122 \\
\hline Incision of cerebral meninges & 0131 & 3.27 & 10,929 \\
\hline Other excision or destruction of lesion or tissue of brain & 0159 & 3.23 & 14,476 \\
\hline Partial excision of pineal gland & 0753 & 3.13 & 64 \\
\hline Excision of accessory spleen & 4193 & 3.13 & 32 \\
\hline Endovascular replacement of aortic valve & 3505 & 2.94 & 68 \\
\hline Total correction of transposition of great vessels, not elsewhere classified & 3584 & 2.94 & 34 \\
\hline Incision of vessel; abdominal arteries & 3806 & 2.93 & 273 \\
\hline Percutaneous insertion of carotid artery stent(s) & 0063 & 2.91 & 103 \\
\hline Incision of vessel; other vessels of head and neck & 3802 & 2.91 & 103 \\
\hline Other surgical occlusion of vessels; other vessels of head and neck & 3882 & 2.85 & 281 \\
\hline Reopening of recent thoracotomy site & 3403 & 2.78 & 144 \\
\hline Transluminal coronary atherectomy & 1755 & 2.78 & 36 \\
\hline Ligation of thoracic duct & 4064 & 2.78 & 36 \\
\hline Other repair of retinal detachment & 1459 & 2.78 & 36 \\
\hline Other surgical occlusion of vessels; intracranial vessels & 3881 & 2.73 & 110 \\
\hline Control of epistaxis by ligation of ethmoidal arteries & 2104 & 2.7 & 37 \\
\hline Repair of endocardial cushion defect with tissue graft & 3563 & 2.63 & 114 \\
\hline Total ostectomy of other facial bone with synchronous reconstruction & 7644 & 2.63 & 38 \\
\hline Open ablation of renal lesion or tissue & 5532 & 2.63 & 38 \\
\hline Open and other replacement of aortic valve with tissue graft & 3521 & 2.61 & 15,928 \\
\hline Ventricular shunt to circulatory system & 232 & 2.6 & 77 \\
\hline Percutaneous angioplasty of extracranial vessel(s) & 0061 & 2.55 & 4,312 \\
\hline Trocar cholecystostomy & 5102 & 2.53 & 79 \\
\hline Soave submucosal resection of rectum & 4841 & 2.5 & 40 \\
\hline Other operations on heart and pericardium & 3799 & 2.44 & 41 \\
\hline Open and other replacement of mitral valve & 3524 & 2.43 & 2,639 \\
\hline Open and other replacement of pulmonary valve with tissue graft & 3527 & 2.41 & 166 \\
\hline Suture of peritoneum & 5464 & 2.38 & 84 \\
\hline Other dental restoration & 2349 & 2.38 & 42 \\
\hline Percutaneous mitral valve repair with implant & 3597 & 2.38 & 42 \\
\hline Open and other replacement of aortic valve & 3522 & 2.37 & 8,633 \\
\hline Creation of conduit between right ventricle and pulmonary artery & 3592 & 2.34 & 128 \\
\hline Other and unspecified repair of atrial septal defect & 3571 & 2.32 & 518 \\
\hline
\end{tabular}


Supplementary Table 4. Continued

\begin{tabular}{|c|c|c|c|}
\hline Procedure name & ICD-9 code & Incidence of stroke (\%) & Procedure frequency \\
\hline Aorta-renal bypass & 3924 & 2.27 & 44 \\
\hline Systemic to pulmonary artery shunt & 390 & 2.26 & 177 \\
\hline Isolation of segment of small intestine & 4551 & 2.25 & 89 \\
\hline Closed (aspiration, percutaneous) biopsy of spleen & 4132 & 2.22 & 45 \\
\hline Incision of vessel; lower limb arteries & 3808 & 2.19 & 1,783 \\
\hline Implant of pulsation balloon & 3761 & 2.18 & 6,913 \\
\hline Annuloplasty & 3533 & 2.18 & 1,465 \\
\hline Other excision of vessel; other vessels of head and neck & 3862 & 2.17 & 46 \\
\hline Percutaneous balloon valvuloplasty & 3596 & 2.1 & 1,095 \\
\hline Incision of pituitary gland & 0772 & 2.08 & 48 \\
\hline Fat graft of skin and subcutaneous tissue & 8687 & 2.06 & 97 \\
\hline Other division of bone; scapula, clavicle, and thorax (ribs and sternum) & 7731 & 2.04 & 49 \\
\hline
\end{tabular}

ICD-9, International Classification of Diseases, 9th revision; NEC, not otherwise specified. 
Supplementary Table 5. ICD-9 codes used in identifying perioperative strokes

Type of stroke

Diagnostic ICD-9 code

Ischemic stroke

43301, 43311, 43321, 43331, 43381, 43391, 43401, 43411, 43491, 436

latrogenic stroke

99702

Hemorrhagic stroke

$430,431,4329$

ICD-9, International Classification of Diseases, 9th revision. 
Supplementary Table 6. Full list of the systematic review

\begin{tabular}{|c|c|c|c|c|c|c|}
\hline Author & Year & Surgical procedure & Country & $\begin{array}{l}\text { Sample } \\
\text { size }\end{array}$ & $\begin{array}{c}\text { Stroke } \\
\text { no. }\end{array}$ & $\begin{array}{c}\text { Stroke incidence } \\
(\%)\end{array}$ \\
\hline Abbas et al. ${ }^{1}$ & 2015 & CABG & Pakistan & 115 & 7 & 6.0 \\
\hline Aboyans et al. ${ }^{2}$ & 2008 & CABG & France & 1,022 & 37 & 3.60 \\
\hline Abraham et al. ${ }^{3}$ & 2002 & Abdominal aortic aneurysm repair & United States & 116 & 1 & 0.90 \\
\hline AbuRahma et al. ${ }^{4}$ & 1996 & CEA & United States & 399 & 7 & 1.75 \\
\hline AbuRahma $^{5}$ & 2004 & CEA & United States & 357 & 10 & 2.80 \\
\hline AbuRahma et al. ${ }^{6}$ & 2008 & CAS & United States & 100 & 2 & 2.0 \\
\hline AbuRahma et al. ${ }^{7}$ & 2010 & CEA & United States & 200 & 2 & 1.0 \\
\hline AbuRahma et al. ${ }^{8}$ & 2010 & CEA and CAS & United States & 192 & 3 & 1.56 \\
\hline AbuRahma et al. ${ }^{9}$ & 2005 & CEA & United States & 187 & 3 & 1.50 \\
\hline AbuRahma et al. ${ }^{10}$ & 2001 & CEA & United States & 144 & 6 & 4.16 \\
\hline AbuRahma et al." & 2007 & CEA & United States & 200 & 6 & 3.0 \\
\hline AbuRahma et al. ${ }^{12}$ & 2002 & CEA & United States & 200 & 7 & 3.50 \\
\hline Ackerstaff et al. ${ }^{13}$ & 1996 & CEA & Netherlands & 301 & 13 & 4.31 \\
\hline Ad et al. ${ }^{14}$ & 2011 & Cox-Maze procedure & United States & 124 & 1 & 0.8 \\
\hline Ad et al. ${ }^{15}$ & 2015 & Mitral valve surgery & United States & 387 & 3 & 0.76 \\
\hline Ad et al. ${ }^{16}$ & 2013 & Cox-Maze procedure & United States & 232 & 4 & 1.70 \\
\hline Ad et al. ${ }^{17}$ & 2017 & Cox-Maze procedure & United States & 709 & 4 & 0.56 \\
\hline Alcantara et al. ${ }^{18}$ & 2014 & CEA & United States & 181 & 0 & 0 \\
\hline Alnasser et al. ${ }^{19}$ & 2017 & Transcatheter valve-in-valve implantation & Canada & 162 & 2 & 1.23 \\
\hline Alonso-Coello et al. ${ }^{20}$ & 2017 & Noncardiac surgeries & Multiple & 8,346 & 60 & 0.72 \\
\hline Amato et al. ${ }^{21}$ & 2015 & CEA & Italy & 202 & 3 & 1.49 \\
\hline Ambrosii et al. ${ }^{22}$ & 2016 & Musculoskeletal system or abdominal cavity surgeries & Moldova & 400 & 2 & 0.50 \\
\hline Ansel et al. ${ }^{23}$ & 2010 & CAS & United States & 257 & 5 & 1.90 \\
\hline Antunes et al. ${ }^{24}$ & 1999 & CABG & Portugal & 107 & 3 & 2.8 \\
\hline Anzola et al..$^{25}$ & 2004 & Patent foramen ovale transcatheter closure & Italy & 140 & 0 & 0 \\
\hline Arnaoutoglou et al. ${ }^{26}$ & 2017 & Endovascular repair of abdominal aortic aneurysm & Greece & 153 & 3 & 1.96 \\
\hline Aronson $^{27}$ & 2009 & Cardiac surgery & United States & 1,405 & 20 & 1.42 \\
\hline Ascher et al. ${ }^{28}$ & 2002 & CEA & United States & 226 & 3 & 1.30 \\
\hline Ascione et al. ${ }^{29}$ & 2004 & CABG & United Kingdom & 686 & 5 & 0.73 \\
\hline Ascione et al. ${ }^{30}$ & 2005 & CABG & United Kingdom & 470 & 6 & 1.27 \\
\hline Ascione et al. ${ }^{31}$ & 2001 & CABG & United Kingdom & 253 & 14 & 5.53 \\
\hline Ascione et al. ${ }^{32}$ & 2002 & CABG & United Kingdom & 4,077 & 45 & 1.10 \\
\hline Asimakopoulos et al. ${ }^{33}$ & 2006 & Off pump CABG & United Kingdom & 251 & 2 & 0.80 \\
\hline Assadian et al..$^{34}$ & 2008 & CEA & Austria & 338 & 2 & 0.60 \\
\hline Assadian et al. ${ }^{35}$ & 2007 & Carotid eversion endarterectomy & Austria & 363 & 5 & 1.38 \\
\hline Assadian et al..$^{36}$ & 2005 & CEA & Austria & 1,210 & 30 & 2.48 \\
\hline Asteriou et al. ${ }^{37}$ & 2013 & CABG & Greece & 200 & 6 & 3.0 \\
\hline Avinee et al. ${ }^{38}$ & 2016 & TAVI & France & 368 & 14 & 3.80 \\
\hline Axisa et al. $^{39}$ & 2002 & Peripheral angioplasty & United Kingdom & 1,377 & 6 & 0.44 \\
\hline Ayad $^{40}$ & 2016 & Percutaneous coronary intervention & Egypt & 160 & 0 & 0 \\
\hline Baklanov et al. ${ }^{41}$ & 2006 & Coronary stenting & United States & 197 & 0 & 0 \\
\hline Ballotta et al. ${ }^{42}$ & 2008 & CEA & Italy & 102 & 0 & 0 \\
\hline Ballotta et al. ${ }^{43}$ & 2005 & Carotid coiling or kinking & Italy & 129 & 0 & 0 \\
\hline Ballotta et al. ${ }^{44}$ & 2008 & CEA & Italy & 374 & 0 & 0 \\
\hline
\end{tabular}


Supplementary Table 6. Continued

\begin{tabular}{|c|c|c|c|c|c|c|}
\hline Author & Year & Surgical procedure & Country & $\begin{array}{l}\text { Sample } \\
\text { size }\end{array}$ & $\begin{array}{c}\text { Stroke } \\
\text { no. }\end{array}$ & $\begin{array}{c}\text { Stroke incidence } \\
(\%)\end{array}$ \\
\hline Ballotta et al. ${ }^{45}$ & 2004 & CEA & Italy & 363 & 3 & 0.77 \\
\hline Ballotta et al. ${ }^{46}$ & 2003 & CEA & Italy & 624 & 4 & 0.64 \\
\hline Ballotta et al. ${ }^{47}$ & 1999 & CEA & Italy & 336 & 5 & 1.49 \\
\hline Ballotta et al. ${ }^{48}$ & 2001 & CEA & Italy & 547 & 5 & 0.91 \\
\hline Ballotta et al. ${ }^{49}$ & 2014 & CEA & Italy & 1,773 & 8 & 0.39 \\
\hline Banach et al. ${ }^{50}$ & 2008 & Open heart surgery & Poland & 260 & 5 & 1.92 \\
\hline Baracchini et al..$^{51}$ & 2012 & eCEA & Italy & 1,294 & 8 & 0.55 \\
\hline Bardia et al. ${ }^{52}$ & 2017 & Isolated cardiac surgery & United States & 763 & 23 & 3.01 \\
\hline Baribeau et al..$^{53}$ & 2002 & Open heart surgery & United States & 228 & 16 & 7.01 \\
\hline Barnes et al. ${ }^{54}$ & 1981 & Coronary or peripheral arterial revascularization & United States & 314 & 1 & 0.32 \\
\hline Barnes et al. ${ }^{55}$ & 1981 & Coronary or peripheral arterial revascularization & United States & 449 & 5 & 1.11 \\
\hline Basic et al. ${ }^{56}$ & 2016 & CEA & Austria & 485 & 6 & 1.24 \\
\hline Bastounis et al. ${ }^{57}$ & 2001 & CEA & Greece & 337 & 0 & 0 \\
\hline Batchelder et al..$^{58}$ & 2015 & CEA & United Kingdom & 100 & 1 & 1.0 \\
\hline Bechtel et al. ${ }^{59}$ & 2000 & CEA and abdominal aortic surgery & Germany & 201 & 1 & 0.50 \\
\hline Becquemin et al..$^{60}$ & 2003 & Carotid stenting and carotid surgery & France & 455 & 9 & 1.98 \\
\hline Bellomo et al..$^{61}$ & 2002 & $\begin{array}{l}\text { All patients undergoing surgeries with a hospital stay } \\
\text { more than } 48 \mathrm{hr}\end{array}$ & Australia & 1,125 & 16 & 1.20 \\
\hline Bellomo et al. ${ }^{.2}$ & 2004 & $\begin{array}{l}\text { Various surgical procedures with a hospital stay more than } \\
48 \mathrm{hr}\end{array}$ & Australia & 2,183 & 23 & 1.05 \\
\hline Berens et al. ${ }^{63}$ & 1992 & Cardiac surgery & United States & 1,087 & 22 & 2.02 \\
\hline Bernhardt et al. ${ }^{64}$ & 2015 & Orthotopic liver transplant & Germany & 134 & 1 & 0.70 \\
\hline Bertolini et al..$^{65}$ & 1997 & Myocardial revascularization & Italy & 100 & 3 & 3.0 \\
\hline Berwanger et al. ${ }^{66}$ & 2016 & $\begin{array}{l}\text { Patients undergoing noncardiac surgeries in patients }>45 \\
\text { with an overnight hospital stay }\end{array}$ & Multiple & 22,815 & 123 & 0.54 \\
\hline Bilecen et al. ${ }^{67}$ & 2013 & Complex cardiac surgery & Netherlands & 1,075 & 31 & 2.88 \\
\hline Bilfinger et al. ${ }^{68}$ & 2000 & Complex cardiac surgery & United States & 1,987 & 38 & 1.8 \\
\hline Binder et al..$^{69}$ & 2015 & TAVI & Switzerland & 598 & 18 & 3.01 \\
\hline Birincioglu et al. ${ }^{70}$ & 1999 & CABG & Turkey & 722 & 13 & 1.80 \\
\hline Bishu et al. ${ }^{71}$ & 2014 & TAVR & United States & 277 & 2 & 0.72 \\
\hline Boehm et al. ${ }^{72}$ & 2007 & CABG & Germany & 1,447 & 35 & 2.41 \\
\hline Börgermann et al. $^{73}$ & 2013 & Aortic valve replacement & Germany & 808 & 9 & 1.11 \\
\hline Borst et al. ${ }^{74}$ & 2007 & CEA & Netherlands & 102 & 1 & 0.98 \\
\hline Borst et al. ${ }^{75}$ & 2001 & CEA & Netherlands & 599 & 20 & 3.34 \\
\hline Borstad et al. ${ }^{76}$ & 1992 & $\begin{array}{l}\text { Patients undergoing major gynecological surgery, laproto- } \\
\text { my, vaginal repair, colposuspension. In procedures lasting } \\
\text { more than a } 30 \text {-min. }\end{array}$ & Norway & 141 & 1 & 0.71 \\
\hline Boudriot et al. ${ }^{77}$ & 2011 & CABG and sirolimus-eluting stenting & Germany & 201 & 2 & 0.99 \\
\hline Bourke et al. ${ }^{78}$ & 2002 & CEA & Australia & 146 & 0 & 0 \\
\hline Braun et al. ${ }^{79}$ & 2002 & Transcatheter closure of patent foramen ovale & Germany & 276 & 0 & 0 \\
\hline Breuer et al. ${ }^{80}$ & 1983 & CABG & United States & 421 & 22 & 5.22 \\
\hline Brittenden et al. ${ }^{81}$ & 2000 & CEA & Scotland & 226 & 6 & 2.65 \\
\hline Broască et al..$^{82}$ & 2013 & lower limb revascularization & Romania & 231 & 0 & 0 \\
\hline Brosig et al..$^{83}$ & 2008 & CEA & Germany & 164 & 12 & 7.31 \\
\hline Budera et al. ${ }^{84}$ & 2012 & Valve and/or coronary surgery & Czech Republic & 224 & 6 & 2.68 \\
\hline
\end{tabular}


Supplementary Table 6. Continued

\begin{tabular}{|c|c|c|c|c|c|c|}
\hline Author & Year & Surgical procedure & Country & $\begin{array}{l}\text { Sample } \\
\text { size }\end{array}$ & $\begin{array}{c}\text { Stroke } \\
\text { no. }\end{array}$ & $\begin{array}{c}\text { Stroke incidence } \\
(\%)\end{array}$ \\
\hline Bull et al. ${ }^{85}$ & 1993 & CABG & Canada & 245 & 5 & 2.04 \\
\hline Camous et al. ${ }^{86}$ & 2014 & Pulmonary endartectomy & France & 207 & 3 & 1.45 \\
\hline Canaud et al. ${ }^{87}$ & 2011 & Thoracic endovascular aortic repair & France & 186 & 0 & 0 \\
\hline Cao et al..$^{88}$ & 1997 & CEA & Italy & 469 & 15 & 2.91 \\
\hline Cao et al. ${ }^{89}$ & 2000 & CEA & Italy & 1,353 & 28 & 2.07 \\
\hline Carrier et al. ${ }^{90}$ & 1997 & CABG & Canada & 224 & 3 & 1.34 \\
\hline Castriota et al. ${ }^{91}$ & 2008 & CAS with cardiopulmonary bypass & Italy & 178 & 1 & 0.56 \\
\hline Chen et al. ${ }^{92}$ & 2009 & Cardiac surgery with cardiopulmonary bypass & United States & 122 & 6 & 4.92 \\
\hline Cieri et al. ${ }^{93}$ & 2008 & CAS & Italy & 223 & 7 & 3.14 \\
\hline Cimochowski et al. ${ }^{94}$ & 1997 & CABG & United States & 111 & 1 & 0.90 \\
\hline Cohen et al. ${ }^{95}$ & 1998 & Valve and/or coronary surgery & Canada & 115 & 2 & 1.74 \\
\hline Cooper et al. ${ }^{96}$ & 2013 & Anaortic off-pump CABG & Australia & 1,135 & 5 & 0.44 \\
\hline Coscas et al. ${ }^{97}$ & 2010 & Open surgery for carotid stenosis & France & 119 & 3 & 2.52 \\
\hline Crouch et al. ${ }^{98}$ & 2015 & TAVI & Australia & 114 & 3 & 2.63 \\
\hline Da Col et al. ${ }^{99}$ & 2008 & Myocardial revascularization & Italy & 257 & 1 & 0.39 \\
\hline Da Silva et al. ${ }^{100}$ & 1996 & CEA & United Kingdom & 108 & 4 & 3.70 \\
\hline Dake et al. ${ }^{101}$ & 1998 & Endovascular repair of descending aortic aneurysm & United States & 103 & 7 & 6.80 \\
\hline D'Angelo et al. ${ }^{102}$ & 2001 & CEA & Italy & 100 & 1 & 1 \\
\hline Darling et al. ${ }^{103}$ & 1998 & CEA & United States & 470 & 5 & 1.06 \\
\hline Darwazah et al. ${ }^{104}$ & 2010 & Myocardial revascularization & Israel & 350 & 0 & 0 \\
\hline M.Davies et al..$^{105}$ & 1993 & CEA & Australia & 389 & 10 & 2.57 \\
\hline J.Davies et al. ${ }^{106}$ & 2016 & SAVR or TAVR & United States & 573 & 11 & 1.92 \\
\hline De Santis et al. ${ }^{107}$ & 2016 & Carotid surgery & Italy & 285 & 4 & 1.28 \\
\hline Debing et al. ${ }^{108}$ & 2007 & CEA & Belgium & 742 & 16 & 2.16 \\
\hline Debing et al. ${ }^{109}$ & 2011 & CEA & Belgium & 1,351 & 18 & 1.33 \\
\hline Deiwick et al. ${ }^{110}$ & 1997 & Open heart surgery & Germany & 101 & 14 & 13.86 \\
\hline Deng et al. ${ }^{111}$ & 2006 & Coronary revascularization & China & 179 & 1 & 0.60 \\
\hline Detter et al..$^{112}$ & 2002 & CABG & Germany & 340 & 0 & 0 \\
\hline Devereaux et al. ${ }^{113}$ & 2011 & Noncardiac surgeries in patients older than $45 \mathrm{yr}$ & Multiple & 432 & 1 & 0.23 \\
\hline Di Biase et al. ${ }^{114}$ & 2014 & Catheter ablation of atrial fibrillation with radiofrequency & Multiple & 428 & 2 & 0.47 \\
\hline Didier et al. ${ }^{115}$ & 2016 & CEA & United States & 25,626 & 86 & 0.34 \\
\hline Dinkel et al. ${ }^{116}$ & 1992 & Carotid surgery & Germany & 125 & 0 & 0 \\
\hline Donaldson et al. ${ }^{117}$ & 1993 & CEA & United States & 396 & 1 & 0.22 \\
\hline Dong et al. ${ }^{118}$ & 2016 & CAS & China & 154 & 9 & 5.84 \\
\hline Dong et al. ${ }^{119}$ & 2017 & CAS & China & 358 & 10 & 2.79 \\
\hline Dorigo et al. ${ }^{120}$ & 2009 & CEA & Italy & 3,324 & 19 & 0.47 \\
\hline Lam et al. ${ }^{121}$ & 2007 & CAS & United States & 133 & 4 & 2.96 \\
\hline Larsen et al..$^{122}$ & 1988 & Noncardiac noncarotid surgeries & Denmark & 2,463 & 6 & 0.20 \\
\hline Lee et al. ${ }^{123}$ & 2013 & CABG & Multiple & 541 & 18 & 3.33 \\
\hline Lennard et al. ${ }^{124}$ & 1999 & CEA & United Kingdom & 252 & 4 & 1.59 \\
\hline Liapis et al. ${ }^{125}$ & 2001 & CEA & Greece & 308 & 7 & 2.07 \\
\hline Likosky et al. ${ }^{126}$ & 2003 & CABG & United States & 11,825 & 177 & 0.99 \\
\hline Linden et al. ${ }^{127}$ & 2007 & Coronary revascularization & United States & 611 & 39 & 6.38 \\
\hline Loponen et al. ${ }^{128}$ & 2003 & CABG & Finland & 1,318 & 34 & 2.58 \\
\hline
\end{tabular}


Supplementary Table 6. Continued

\begin{tabular}{|c|c|c|c|c|c|c|}
\hline Author & Year & Surgical procedure & Country & $\begin{array}{l}\text { Sample } \\
\text { size }\end{array}$ & $\begin{array}{c}\text { Stroke } \\
\text { no. }\end{array}$ & $\begin{array}{c}\text { Stroke incidence } \\
(\%)\end{array}$ \\
\hline Love et al. ${ }^{129}$ & 2000 & CEA & Australia & 443 & 8 & 1.80 \\
\hline Lübke et al. ${ }^{130}$ & 2015 & CEA & Germany & 1,880 & 28 & 1.49 \\
\hline MacDonald et al. ${ }^{131}$ & 1998 & CABG & Canada & 100 & 6 & 6 \\
\hline Mandeville et al. ${ }^{132}$ & 2015 & $\begin{array}{l}\text { Bifurcation resection and interposition of a polytetrafluor- } \\
\text { ethylene graft and CEA }\end{array}$ & Belgium & 153 & 4 & 2.61 \\
\hline Mattos et al. ${ }^{133}$ & 1992 & CEA & United States & 478 & 16 & 2.94 \\
\hline McCollum et al. ${ }^{134}$ & 1997 & Carotid surgery & Multiple & 709 & 15 & 2.11 \\
\hline McKhann et al. ${ }^{135}$ & 2002 & CABG & United States & 2,711 & 72 & 2.66 \\
\hline Mitchell et al. ${ }^{136}$ & 1999 & Thoracic endovascular aortic repair & United States & 103 & 7 & 6.80 \\
\hline Mukerji et al. ${ }^{137}$ & 2015 & CEA & United Kingdom & 728 & 17 & 2.33 \\
\hline Mullenix et al. ${ }^{138}$ & 2002 & CEA & United States & 267 & 6 & 2.24 \\
\hline Naylor et al. ${ }^{139}$ & 2000 & CEA & United Kingdom & 500 & 4 & 0.80 \\
\hline Newman et al..$^{140}$ & 1996 & CABG & United States & 2,417 & 68 & 3.20 \\
\hline Nicholls et al. ${ }^{141}$ & 1985 & CEA & United States & 134 & 2 & 1.49 \\
\hline Nordanstig et al. ${ }^{142}$ & 2017 & CEA & Sweeden & 418 & 11 & 2.63 \\
\hline Ott et al..$^{143}$ & 1980 & CEA & United States & 240 & 4 & 1.29 \\
\hline Pell et al..$^{144}$ & 2004 & CEA & Scotland & 877 & 22 & 2.51 \\
\hline Radu et al. ${ }^{145}$ & 2013 & CAS & Germany & 279 & 6 & 2.15 \\
\hline Rafiq et al. ${ }^{146}$ & 2012 & CABG & Denmark & 194 & 10 & 3.09 \\
\hline Roach et al. ${ }^{147}$ & 1996 & CABG & United States & 2,108 & 63 & 2.99 \\
\hline Saini et al. ${ }^{148}$ & 2017 & Minimally invasive surgical ablation for atrial fibrillation & United States & 109 & 1 & 0.92 \\
\hline Salazar et al. ${ }^{149}$ & 2001 & Cardiac surgery & United States & 5,971 & 214 & 3.58 \\
\hline Salem et al. ${ }^{150}$ & 2011 & CEA & United Kingdom & 109 & 2 & 1.83 \\
\hline Samson et al. ${ }^{151}$ & 1998 & CEA & United States & 654 & 11 & 1.68 \\
\hline Sandison et al. ${ }^{152}$ & 2000 & CEA & United Kingdom & 333 & 8 & 2.40 \\
\hline Santo et al. ${ }^{153}$ & 2008 & Cardiac surgery & Italy & 925 & 9 & 0.97 \\
\hline Schmitz et al. ${ }^{154}$ & 2003 & Cardiac surgery & Germany & 582 & 8 & 1.37 \\
\hline Schneider et al. ${ }^{155}$ & 1997 & CEA & United States & 186 & 7 & 3.48 \\
\hline Schoenefeld et al. ${ }^{156}$ & 2012 & CEA & Germany & 540 & 19 & 3.52 \\
\hline Schoof et al. ${ }^{157}$ & 2007 & $\mathrm{CABG}$ and/or valve surgery & Germany & 2,797 & 67 & 2.40 \\
\hline Senay et al. ${ }^{158}$ & 2011 & CABG & Turkey & 3,248 & 32 & 0.99 \\
\hline Shapira et al. ${ }^{159}$ & 2006 & CABG & United States & 2,450 & 28 & 1.14 \\
\hline Shaw et al. ${ }^{160}$ & 1985 & CABG & United Kingdom & 312 & 15 & 4.81 \\
\hline Spes et al. ${ }^{161}$ & 2007 & CAS & Germany & 371 & 9 & 2.22 \\
\hline Stabile et al. ${ }^{162}$ & 2010 & CAS & Italy & 1,300 & 12 & 0.92 \\
\hline Subban et al. ${ }^{163}$ & 2016 & TAVI & Australia & 209 & 9 & 4.31 \\
\hline Suematsu et al. ${ }^{164}$ & 2000 & CABG & Japan & 179 & 6 & 3.35 \\
\hline Takach et al. ${ }^{165}$ & 1996 & CEA & United States & 248 & 2 & 0.75 \\
\hline Tatoulis et al. ${ }^{166}$ & 1999 & Coronary revascularization & Australia & 3,220 & 26 & 0.81 \\
\hline Trehan et al. ${ }^{167}$ & 1997 & CABG & India & 792 & 6 & 0.76 \\
\hline Trehan et al. ${ }^{168}$ & 2000 & CABG & India & 3,660 & 35 & 0.96 \\
\hline Verhoeven et al. ${ }^{169}$ & 2005 & CEA & Netherlands & 200 & 11 & 5.47 \\
\hline Veselka et al. ${ }^{170}$ & 2009 & CAS & Czech Republic & 176 & 2 & 0.93 \\
\hline Walker et al. ${ }^{171}$ & 1995 & CEA & Multiple & 825 & 15 & 1.82 \\
\hline Walkes et al. ${ }^{172}$ & 2002 & CABG & United States & 1,069 & 31 & 2.90 \\
\hline
\end{tabular}


Supplementary Table 6. Continued

\begin{tabular}{|c|c|c|c|c|c|c|}
\hline Author & Year & Surgical procedure & Country & $\begin{array}{l}\text { Sample } \\
\text { size }\end{array}$ & $\begin{array}{c}\text { Stroke } \\
\text { no. }\end{array}$ & $\begin{array}{c}\text { Stroke incidence } \\
(\%)\end{array}$ \\
\hline Weimar et al. ${ }^{173}$ & 2012 & Cox-Maze procedure & United States & 212 & 2 & 0.94 \\
\hline Weinstein ${ }^{174}$ & 2001 & CABG & United States & 2,217 & 51 & 2.30 \\
\hline Wenaweser et al..$^{175}$ & 2011 & TAVI & Switzerland & 256 & 9 & 3.52 \\
\hline Burns et al. ${ }^{176}$ & 1991 & CEA & Australia & 223 & 14 & 5.86 \\
\hline Wöhrle et al. ${ }^{177}$ & 2016 & TAVI & Germany & 235 & 5 & 2.13 \\
\hline Woelfle et al. ${ }^{178}$ & 2002 & CEA & Germany & 111 & 3 & 2.70 \\
\hline Wolman et al. ${ }^{179}$ & 1999 & Cardiac and coronary surgery & United States & 273 & 21 & 7.69 \\
\hline Wong et al. ${ }^{180}$ & 1999 & CEA & Canada & 184 & 8 & 4.35 \\
\hline Yadeau et al. ${ }^{181}$ & 2011 & Ambulatory shoulder surgery & United States & 1,169 & 0 & 0 \\
\hline Young et al. ${ }^{182}$ & 1996 & CEA & United States & 721 & 10 & 1.39 \\
\hline Zannetti et al. ${ }^{183}$ & 1999 & CEA & Italy & 1,305 & 13 & 1.00 \\
\hline Zarins et al. $^{184}$ & 2009 & CEA and CAS & United States & 397 & 12 & 3.02 \\
\hline Zhang et al. ${ }^{185}$ & 2015 & Aortic valve replacement & Germany & 113 & 1 & 0.88 \\
\hline Ziemann et al. ${ }^{186}$ & 2017 & Cardiac surgery & Germany & 983 & 14 & 1.42 \\
\hline Zipfel et al. ${ }^{187}$ & 2008 & Endovascular repair of abdominal aortic aneurysm & Germany & 126 & 4 & 3.17 \\
\hline
\end{tabular}

CABG, coronary artery bypass grafting; CEA, carotid endarterectomy; CAS, carotid artery stenting; eCEA, eversion carotid endarterectomy; TAVI, transcatheter aortic valve implantation; TAVR, transcatheter aortic valve replacement; SAVR, surgical aortic valve replacement. 


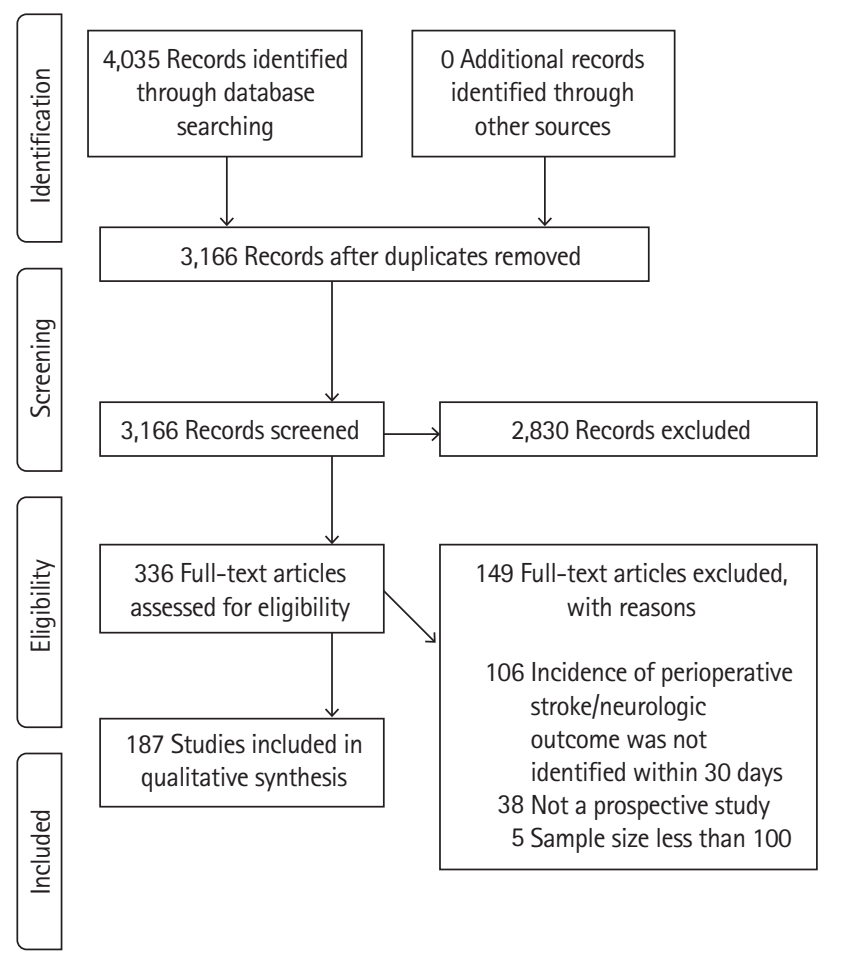

Supplementary Figure 1. PRISMA 2009 flow diagram. Adapted from Moher et al. ${ }^{188}$ PRISMA, Preferred Reporting Items for Systematic Reviews and Meta-Analyses. 


\section{Supplementary References}

1. Abbas S, Riaz W, Khwaja IA, Iqbal M, Tufail Z, Waheed A. Mean arterial pressure and pulse pressure, influence on postoperative renal and neurological outcomes in elderly patients undergoing coronary revascularization. Pak Heart J 2015;48:194199.

2. Aboyans V, Frank M, Nubret $K$, Lacroix P, Laskar M. Heart rate and pulse pressure at rest are major prognostic markers of early postoperative complications after coronary bypass surgery. Eur J Cardiothorac Surg 2008;33:971-976.

3. Abraham CZ, Chuter TA, Reilly LM, Okuhn SP, Pethan LK, Kerlan $\mathrm{RB}$, et al. Abdominal aortic aneurysm repair with the Zenith stent graft: short to midterm results. J Vasc Surg 2002; 36:217-225.

4. AbuRahma AF, Khan JH, Robinson PA, Saiedy S, Short YS, Boland JP, et al. Prospective randomized trial of carotid endarterectomy with primary closure and patch angioplasty with saphenous vein, jugular vein, and polytetrafluoroethylene: perioperative (30-day) results. J Vasc Surg 1996;24:998-1007.

5. Aburahma AF. Patch closure improves results with carotid endarterectomy. Semin Vasc Surg 2004;17:243-252.

6. AbuRahma AF, Bates MC, Eads K, Armistead L, Flaherty SK. Safety and efficacy of carotid angioplasty/stenting in 100 consecutive high surgical risk patients: immediate and longterm follow-up. Vasc Endovascular Surg 2008;42:433-439.

7. Aburahma AF, Stone PA, Hass SM, Dean LS, Habib J, Keiffer T, et al. Prospective randomized trial of routine versus selective shunting in carotid endarterectomy based on stump pressure. J Vasc Surg 2010;51:1133-1138.

8. AbuRahma AF, Abu-Halimah $S$, Hass SM, Nanjundappa A, Stone PA, Mousa A, et al. Carotid artery stenting outcomes are equivalent to carotid endarterectomy outcomes for patients with post-carotid endarterectomy stenosis. J Vasc Surg 2010;52:1180-1187.

9. AbuRahma AF, Stone PA, Welch CA, Hofeldt MJ, Hass SM, Perry W. Prospective study of carotid endarterectomy with modified polytetrafluoroethylene (ACUSEAL) patching: early and late results. J Vasc Surg 2005;41:789-793.

10. AbuRahma AF, Robinson PA, Hannay RS, Hudson J, Cutlip L. Prospective controlled study of carotid endarterectomy with hemashield patch: is it thrombogenic? Vasc Surg 2001;35: 167-174.

11. AbuRahma AF, Stone PA, Flaherty SK, AbuRahma Z. Prospective randomized trial of ACUSEAL (Gore-Tex) versus Hemashield-Finesse patching during carotid endarterectomy: early results. J Vasc Surg 2007;45:881-884.

12. AbuRahma AF, Hannay RS, Khan JH, Robinson PA, Hudson
JK, Davis EA. Prospective randomized study of carotid endarterectomy with polytetrafluoroethylene versus collagen-impregnated Dacron (Hemashield) patching: perioperative (30day) results. J Vasc Surg 2002;35:125-130.

13. Aackerstaff RG, Jansen $C$, Moll FL. Carotid endarterectomy and intraoperative emboli detection: correlation of clinical, transcranial Doppler, and magnetic resonance findings. Echocardiography 1996;13:543-550.

14. Ad N, Henry L, Hunt S. The concomitant cryosurgical CoxMaze procedure using Argon based cryoprobes: 12 month results. J Cardiovasc Surg (Torino) 2011;52:593-599.

15. Ad N, Holmes SD, Shuman DJ, Pritchard G, Massimiano PS. Minimally invasive mitral valve surgery without aortic crossclamping and with femoral cannulation is not associated with increased risk of stroke compared with traditional mitral valve surgery: a propensity score-matched analysis. Eur J Cardiothorac Surg 2015;48:868-872.

16. 16. Ad N, Holmes SD, Massimiano PS, Pritchard G, Stone LE, Henry $L$. The effect of the Cox-maze procedure for atrial fibrillation concomitant to mitral and tricuspid valve surgery. J Thorac Cardiovasc Surg 2013;146:1426-1435.

17. 17. Ad N, Holmes SD, Rongione AJ, Massimiano PS, Fornaresio LM. Does surgical ablation energy source affect longterm success of the concomitant Cox Maze procedure? Ann Thorac Surg 2017;104:29-35.

18. Alcantara SD, Wuamett JC, Lantis JC 2nd, Ulkatan S, Bamberger $\mathrm{P}$, Mendes $\mathrm{D}$, et al. Outcomes of combined somatosensory evoked potential, motor evoked potential, and electroencephalography monitoring during carotid endarterectomy. Ann Vasc Surg 2014;28:665-672.

19. Alnasser $S$, Cheema AN, Simonato $M$, Barbanti M, Edwards J, Kornowski $R$, et al. Matched comparison of self-expanding transcatheter heart valves for the treatment of failed aortic surgical bioprosthesis: insights from the Valve-in-Valve International Data Registry (VIVID). Circ Cardiovasc Interv 2017;10: e004392.

20. Alonso-Coello P, Cook D, Xu SC, Sigamani A, Berwanger O, Sivakumaran $S$, et al. Predictors, prognosis, and management of new clinically important atrial fibrillation after noncardiac surgery: a prospective cohort study. Anesth Analg 2017;125: 162-169.

21. Amato $B$, Compagna $R$, Amato $M$, Gallelli $L$, de Franciscis $S$, Serra R. Aterofisiol $\left({ }^{\circledR}\right)$ in carotid plaque evolution. Drug Des Devel Ther 2015;9:3877-3884.

22. Ambrosii T, Şandru S, Belîi A. The prevalence of perioperative complications in patients with and without obstructive sleep apnoea: a prospective cohort study. Rom J Anaesth Intensive Care 2016;23:103-110. 
23. Ansel GM, Hopkins LN, Jaff MR, Rubino P, Bacharach JM, Scheinert D, et al. Safety and effectiveness of the INVATEC MO.MA proximal cerebral protection device during carotid artery stenting: results from the ARMOUR pivotal trial. Catheter Cardiovasc Interv 2010;76:1-8.

24. Antunes PE, Ferrão de Oliveira J, Antunes MJ. Non-cardioplegic coronary surgery in patients with severe left ventricular dysfunction. Eur J Cardiothorac Surg 1999;16:331-336.

25. Anzola GP, Morandi E, Casilli F, Onorato E. Does transcatheter closure of patent foramen ovale really "shut the door?": a prospective study with transcranial Doppler. Stroke 2004;35: 2140-2144.

26. Arnaoutoglou E, Kouvelos G, Tzimas P, Laou E, Bouris V, Papadopoulos G, et al. Relationship between normal preoperative white blood cell count and major adverse events after endovascular repair for abdominal aortic aneurysm: results of a pilot study. J Clin Anesth 2017;36:201-205.

27. Aronson S. Clevidipine in the treatment of perioperative hypertension: assessing safety events in the ECLIPSE trials. Expert Rev Cardiovasc Ther 2009;7:465-472.

28. Ascher E, Markevich N, Hingorani AP, Kallakuri S, Gunduz Y. Internal carotid artery flow volume measurement and other intraoperative duplex scanning parameters as predictors of stroke after carotid endarterectomy. J Vasc Surg 2002;35: 439-444.

29. Ascione R, Reeves BC, Pano M, Angelini GD. Trainees operating on high-risk patients without cardiopulmonary bypass: a high-risk strategy? Ann Thorac Surg 2004;78:26-33.

30. Ascione R, Ghosh A, Rogers CA, Cohen A, Monk C, Angelini GD. In-hospital patients exposed to clopidogrel before coronary artery bypass graft surgery: a word of caution. Ann Thorac Surg 2005;79:1210-1216.

31. Ascione R, Nason G, Al-Ruzzeh S, Ko C, Ciulli F, Angelini GD. Coronary revascularization with or without cardiopulmonary bypass in patients with preoperative nondialysis-dependent renal insufficiency. Ann Thorac Surg 2001;72:2020-2025.

32. Ascione $R$, Reeves $B C$, Chamberlain MH, Ghosh AK, Lim KH, Angelini GD. Predictors of stroke in the modern era of coronary artery bypass grafting: a case control study. Ann Thorac Surg 2002;74:474-480.

33. Asimakopoulos G, Karagounis AP, Valencia O, Rose D, Niranjan $\mathrm{G}$, Chandrasekaran V. How safe is it to train residents to perform off-pump coronary artery bypass surgery? Ann Thorac Surg 2006;81:568-572.

34. Assadian $A$, Knöbl $P$, Hübl W, Senekowitsch $C$, Klingler $A$, Pfaffelmeyer $N$, et al. Safety and efficacy of intravenous enoxaparin for carotid endarterectomy: a prospective randomized pilot trial. J Vasc Surg 2008;47:537-542.
35. Assadian A, Rotter R, Assadian O, Senekowitsch C, Hagmüller GW, Hübl W. Homocysteine and early re-stenosis after carotid eversion endarterectomy. Eur J Vasc Endovasc Surg 2007;33: 144-148.

36. Assadian A, Senekowitsch C, Assadian O, Ptakovsky H, Hagmüller GW. Perioperative morbidity and mortality of carotid artery surgery under loco-regional anaesthesia. Vasa 2005;34: 41-45.

37. Asteriou C, Antonitsis P, Argiriadou H, Deliopoulos A, Konstantinou D, Foroulis $C$, et al. Minimal extracorporeal circulation reduces the incidence of postoperative major adverse events after elective coronary artery bypass grafting in highrisk patients: a single-institutional prospective randomized study. Perfusion 2013;28:350-356.

38. Avinée G, Durand E, Elhatimi S, Bauer F, Glinel B, Dacher JN, et al. Trends over the past 4 years in population characteristics, 30-day outcomes and 1-year survival in patients treated with transcatheter aortic valve implantation. Arch Cardiovasc Dis 2016;109:457-464.

39. Axisa B, Fishwick G, Bolia A, Thompson MM, London NJ, Bell $\mathrm{PR}$, et al. Complications following peripheral angioplasty. Ann R Coll Surg Engl 2002;84:39-42.

40. Ayad SW. Aspiration versus no aspiration during primary PCI for ST-segment elevation myocardial infarction. Egypt Hear $t$ J 2016;68:147-152.

41. Baklanov DV, Marcu CB, Juhasz DF, Caracciolo EA, Chawarski MC, Donohue TJ. Coronary stenting is safe and effective in a high-risk octogenarian patient cohort. Conn Med 2006;70: 15-19.

42. Ballotta E, Meneghetti G, Da Giau G, Manara R, Saladini M, Baracchini C. Carotid endarterectomy within 2 weeks of minor ischemic stroke: a prospective study. J Vasc Surg 2008; 48:595-600.

43. Ballotta E, Thiene G, Baracchini C, Ermani M, Militello C, Da Giau $G$, et al. Surgical vs medical treatment for isolated internal carotid artery elongation with coiling or kinking in symptomatic patients: a prospective randomized clinical study. J Vasc Surg 2005;42:838-846.

44. Ballotta E, Manara R, Meneghetti G, Ermani M, Da Giau G, Baracchini C. Diabetes and asymptomatic carotid stenosis: does diabetic disease influence the outcome of carotid endarterectomy?: a 10-year single center experience. Surgery 2008;143:519-525.

45. Ballotta E, Da Giau G, Baracchini C, Manara R. Carotid endarterectomy in high-risk patients: a challenge for endovascular procedure protocols. Surgery 2004;135:74-80.

46. Ballotta E, Da Giau G. Selective shunting with eversion carotid endarterectomy. J Vasc Surg 2003;38:1045-1050. 
47. Ballotta E, Da Giau G, Saladini M, Abbruzzese E, Renon L, Toniato $A$. Carotid endarterectomy with patch closure versus carotid eversion endarterectomy and reimplantation: a prospective randomized study. Surgery 1999;125:271-279.

48. Ballotta E, Da Giau G, Renon L. Is diabetes mellitus a risk factor for carotid endarterectomy?: a prospective study. Surgery 2001;129:146-152.

49. Ballotta E, Toniato A, Da Giau G, Lorenzetti R, Da Roit A, Baracchini C. Durability of eversion carotid endarterectomy. J Vasc Surg 2014;59:1274-1281.

50. Banach M, Kazmierski J, Kowman M, Okonski PK, Sobow T, Kloszewska I, et al. Atrial fibrillation as a nonpsychiatric predictor of delirium after cardiac surgery: a pilot study. Med Sci Monit 2008;14:CR286-CR291.

51. Baracchini C, Saladini M, Lorenzetti R, Manara R, Da Giau G, Ballotta E. Gender-based outcomes after eversion carotid endarterectomy from 1998 to 2009. J Vasc Surg 2012;55: 338-345.

52. Bardia A, Khabbaz K, Mueller A, Mathur P, Novack V, Talmor $D$, et al. The association between preoperative hemoglobin A1C and postoperative glycemic variability on 30-day major adverse outcomes following isolated cardiac valvular surgery. Anesth Analg 2017;124:16-22.

53. Baribeau Y, Westbrook BM, Charlesworth DC, Hearne MJ, Bradley WA, Maloney CT. Brachial gradient in cardiac surgical patients. Circulation 2002;106(12 Suppl 1):I11-I13.

54. Barnes RW, Marszalek PB. Asymptomatic carotid disease in the cardiovascular surgical patient: is prophylactic endarterectomy necessary? Stroke 1981;12:497-500.

55. Barnes RW, Liebman PR, Marszalek PB, Kirk CL, Goldman MH. The natural history of asymptomatic carotid disease in patients undergoing cardiovascular surgery. Surgery 1981;90: 1075-1083.

56. Basic J, Assadian A, Strassegger J, Senekowitsch C, Wickenhauser $G$, Koulas $S$, et al. Degree of contralateral carotid stenosis improves preoperative risk stratification of patients with asymptomatic ipsilateral carotid stenosis. J Vasc Surg 2016;63:82-88.

57. Bastounis E, Filis K, Georgopoulos S, Klonaris C, Xeromeritis $N$, Papalambros E. Current practice: routine use of shunting in carotid endarterectomy: cost reduction and surgical training. Int Angiol 2001;20:218-224.

58. Batchelder A, Hunter J, Cairns V, Sandford R, Munshi A, Naylor AR. Dual antiplatelet therapy prior to expedited carotid surgery reduces recurrent events prior to surgery without significantly increasing peri-operative bleeding complications. Eur J Vasc Endovasc Surg 2015;50:412-419.

59. Bechtel JF, Bartels C, Hopstein S, Horsch S. Carotid endarter- ectomy prior to major abdominal aortic surgery. J Cardiovasc Surg (Torino) 2000;41:269-273.

60. Becquemin JP, Ben El Kadi H, Desgranges P, Kobeiter H. Carotid stenting versus carotid surgery: a prospective cohort study. J Endovasc Ther 2003;10:687-694.

61. Bellomo R, Goldsmith D, Russell S, Uchino S. Postoperative serious adverse events in a teaching hospital: a prospective study. Med J Aust 2002;176:216-218.

62. Bellomo R, Goldsmith D, Uchino S, Buckmaster J, Hart G, Opdam $\mathrm{H}$, et al. Prospective controlled trial of effect of medical emergency team on postoperative morbidity and mortality rates. Crit Care Med 2004;32:916-921.

63. Berens ES, Kouchoukos NT, Murphy SF, Wareing TH. Preoperative carotid artery screening in elderly patients undergoing cardiac surgery. J Vasc Surg 1992;15:313-323.

64. Bernhardt M, Pflugrad H, Goldbecker A, Barg-Hock $H_{\text {, }}$ Knitsch W, Klempnauer J, et al. Central nervous system complications after liver transplantation: common but mostly transient phenomena. Liver Transp/ 2015;21:224-232.

65. Bertolini P, Santini F, Montalbano G, Pessotto R, Mazzucco A. Single aortic cross-clamp technique in coronary surgery: a prospective randomized study. Eur J Cardiothorac Surg 1997; 12:413-419.

66. Berwanger O, Le Manach Y, Suzumura EA, Biccard B, Srinathan SK, Szczeklik W, et al. Association between pre-operative statin use and major cardiovascular complications among patients undergoing non-cardiac surgery: the VISION study. Eur Heart J 2016;37:177-185.

67. Bilecen S, Peelen LM, Kalkman CJ, Spanjersberg AJ, Moons $\mathrm{KG}$, Nierich AP. Fibrinogen concentrate therapy in complex cardiac surgery. J Cardiothorac Vasc Anesth 2013;27:12-17.

68. Bilfinger TV, Reda H, Giron F, Seifert FC, Ricotta JJ. Coronary and carotid operations under prospective standardized conditions: incidence and outcome. Ann Thorac Surg 2000;69: 1792-1798.

69. Binder RK, Stortecky S, Heg D, Tueller D, Jeger R, Toggweiler S, et al. Procedural results and clinical outcomes of transcatheter aortic valve implantation in Switzerland: an observational cohort study of Sapien 3 versus Sapien XT Transcatheter Heart Valves. Circ Cardiovasc Interv 2015;8:e002653.

70. Birincioğlu $C L$, Bayazit $M$, Ulus $A T$, Bardakçi $H$, Küçüker $S A$, Taşdemir 0. Carotid disease is a risk factor for stroke in coronary bypass operations. J Card Surg 1999;14:417-423.

71. Bishu K, Suri RM, Nkomo VT, Kane GC, Greason KL, Reeder $\mathrm{GS}$, et al. Prognostic impact of pulmonary artery systolic pressure in patients undergoing transcatheter aortic valve replacement for aortic stenosis. Am J Cardiol 2014;114:15621567. 
72. Boehm J, Grammer JB, Lehnert F, Dietrich W, Wagenpfeil S, Wildhirt SM, et al. Factor $V$ Leiden does not affect bleeding in aprotinin recipients after cardiopulmonary bypass. Anesthesiology 2007;106:681-686.

73. Borgermann J, Furukawa N, Aboud A, Renner A, Benzinger M, Hakim-Meibodi $K$, et al. Minimally invasive versus standard approach aortic valve replacement: a propensity score analysis of 808 patients. 2003 Annual Scientific Meeting of Innovations: Technology and Techniques in Cardiothoracic and Vascular Surgery; 2003 Jun 12-15; Prague, CZ.

74. De Borst GJ, Hilgevoord AA, de Vries JP, van der Mee M, Moll $\mathrm{FL}$, van de Pavoordt HD, et al. Influence of antiplatelet therapy on cerebral micro-emboli after carotid endarterectomy using postoperative transcranial Doppler monitoring. Eur J Vasc Endovasc Surg 2007;34:135-142.

75. de Borst GJ, Moll FL, van de Pavoordt HD, Mauser HW, Kelder JC, Ackerstaf RG. Stroke from carotid endarterectomy: when and how to reduce perioperative stroke rate? Eur J Vasc Endovasc Surg 2001;21:484-489.

76. Borstad $E$, Urdal K, Handeland G, Abildgaard U. Comparison of low molecular weight heparin vs. unfractionated heparin in gynecological surgery. II: reduced dose of low molecular weight heparin. Acta Obstet Gynecol Scand 1992;71:471475.

77. Boudriot $E_{1}$ Thiele $H$, Walther $T$, Liebetrau $C$, Boeckstegers $P$, Pohl T, et al. Randomized comparison of percutaneous coronary intervention with sirolimus-eluting stents versus coronary artery bypass grafting in unprotected left main stem stenosis. J Am Coll Cardiol 2011;57:538-545.

78. Bourke BM, Crimmins DS. Early control of the distal internal carotid artery during endarterectomy: achievability and results. J Vasc Surg 2002;36:70-74.

79. Braun MU, Fassbender D, Schoen SP, Haass M, Schraeder R, Scholtz W, et al. Transcatheter closure of patent foramen ovale in patients with cerebral ischemia. J Am Coll Cardiol 2002;39:2019-2025.

80. Breuer AC, Furlan AJ, Hanson MR, Lederman RJ, Loop FD, Cosgrove DM, et al. Central nervous system complications of coronary artery bypass graft surgery: prospective analysis of 421 patients. Stroke 1983;14:682-687.

81. Brittenden J, Bradbury AW. Are we still performing inappropriate carotid endarterectomy? Eur J Vasc Endovasc Surg 2000;20:158-162.

82. Broască M, Nedelcu DE. Study on the chronic antithrombotic treatment after surgical revascularizations in the peripheral arterial disease. Farmacia 2013;61:492-502.

83. Brosig T, Hoinkes A, Seitz RJ, Sandmann W, Huber R, Siebler M. Ultrasound turbulence index during thromboendarterec- tomy predicts postoperative cerebral microembolism. Cerebrovasc Dis 2008;26:87-92.

84. Budera P, Straka Z, Osmančik P, Vaněk T, Jelínek Š, Hlavička J, et al. Comparison of cardiac surgery with left atrial surgical ablation vs. cardiac surgery without atrial ablation in patients with coronary and/or valvular heart disease plus atrial fibrillation: final results of the PRAGUE-12 randomized multicentre study. Eur Heart J 2012;33:2644-2652.

85. Bull DA, Neumayer LA, Hunter GC, Keksz J, Sethi GK, McIntyre $K E$, et al. Risk factors for stroke in patients undergoing coronary artery bypass grafting. Cardiovasc Surg 1993; 1:182-185.

86. Camous J, Decrombecque $T$, Louvain-Quintard V, Doubine $S$, Dartevelle P, Stéphan F. Outcomes of patients with antiphospholipid syndrome after pulmonary endarterectomy. Eur J Cardiothorac Surg 2014;46:116-120.

87. Canaud L, Alric P, Gandet T, Albat B, Marty-Ané $C$, Berthet JP. Surgical conversion after thoracic endovascular aortic repair. J Thorac Cardiovasc Surg 2011;142:1027-1031.

88. Cao P, Giordano G, De Rango P, Caporali S, Lenti M, Ricci S, et al. Eversion versus conventional carotid endarterectomy: a prospective study. Eur J Vasc Endovasc Surg 1997;14:96-104.

89. Cao P, Giordano G, De Rango P, Zannetti S, Chiesa R, Coppi $G$, et al. Eversion versus conventional carotid endarterectomy: late results of a prospective multicenter randomized trial. J Vasc Surg 2000;31(1 Pt 1):19-30.

90. Carrier M, Pelletier LC, Searle NR. Does retrograde administration of blood cardioplegia improve myocardial protection during first operation for coronary artery bypass grafting? Ann Thorac Surg 1997;64:1256-1262.

91. Castriota F, de Campos Martins EC, Setacci C, Manetti R, Khamis $\mathrm{H}$, Spagnolo $B$, et al. Cutting balloon angioplasty in percutaneous carotid interventions. J Endovasc Ther 2008; 15:655-662.

92. Chen J, Zimmerman RA, Jarvik GP, Nord AS, Clancy RR, Wernovsky $G$, et al. Perioperative stroke in infants undergoing open heart operations for congenital heart disease. Ann Thorac Surg 2009;88:823-829.

93. Cieri E, De Rango P, Maccaroni MR, Spaccatini A, Caso V, Cao $P$. Is haemodynamic depression during carotid stenting a predictor of peri-procedural complications? Eur J Vasc Endovasc Surg 2008;35:399-404.

94. Cimochowski GE, Harostock MD, Foldes PJ. Minimal operative mortality in patients undergoing coronary artery bypass with significant left ventricular dysfunction by maximization of metabolic and mechanical support. J Thorac Cardiovasc Surg 1997;113:655-666.

95. Cohen G, Ivanov J, Weisel RD, Rao V, Mohabeer MK, Mickle 
DA. Aprotinin and dipyridamole for the safe reduction of postoperative blood loss. Ann Thorac Surg 1998;65:674-683.

96. Cooper EA, Edelman JJ, Black D, Brereton RJ, Ross DE, Bannon PG, et al. Anaortic off-pump coronary artery bypass grafting in the elderly and very elderly. Heart Lung Circ 2013;22:989-995.

97. Coscas R, Rhissassi B, Gruet-Coquet N, Couture T, de Tymowski $C$, Chiche $L$, et al. Open surgery remains a valid option for the treatment of recurrent carotid stenosis. J Vasc Surg 2010;51:1124-1132.

98. Crouch G, Sinhal A, Rice G, Baker R, Bennetts J. Long term outcomes of an Australian TAVI program: better than PARTNER? Heart Lung Circ 2015;24 Suppl 1:e16.

99. Da Col U, Di Bella I, Pasquino $S$, Ramoni E, Paris M, Stracci $F_{1}$ et al. Off-pump technique: a systematic alternative for myocardial revascularization? J Cardiovasc Med (Hagerstown) 2008;9:899-904.

100. Da Silva AF, McCollum P, Szymanska T, de Cossart L. Prospective study of carotid endarterectomy and contralateral carotid occlusion. Br J Surg 1996;83:1370-1372.

101. Dake MD, Miller DC, Mitchell RS, Semba CP, Moore KA, Sakai T. The "first generation" of endovascular stent-grafts for patients with aneurysms of the descending thoracic aorta. J Thorac Cardiovasc Surg 1998;116:689-704.

102. D'Angelo V, Catapano G, Bozzini V, Catapano D, De Vivo $P_{1}$ Del Gaudio A, et al. Propofol EEG burst suppression in carotid endarterectomy. J Neurosurg Sci 2001;45:157-162.

103. Darling RC 3rd, Dylewski M, Chang BB, Paty PS, Kreienberg $P B$, Lloyd $W E$, et al. Combined carotid endarterectomy and coronary artery bypass grafting does not increase the risk of perioperative stroke. Cardiovasc Surg 1998;6:448-452.

104. Darwazah AK, Osman M, Sharabati B. Use of off-pump coronary artery bypass surgery among patients with malignant disease. J Card Surg 2010;25:1-4.

105. Davies MJ, Mooney PH, Scott DA, Silbert BS, Cook RJ. Neurologic changes during carotid endarterectomy under cervical block predict a high risk of postoperative stroke. Anesthesiology 1993;78:829-833.

106. Davies JE Jr, McAlexander WW, Sasse MF, Leesar MA, Melby SJ, Singh SP, et al. Impact of transcatheter aortic valve replacement on surgical volumes and outcomes in a tertiary academic cardiac surgical practice. J Am Coll Surg 2016;222: 645-655.

107. De Santis F, Chaves Brait CM, Pattaro C, Cesareo V, Di Cintio V. A prospective nonrandomized study on carotid surgery performed under general anesthesia without intraoperative cerebral monitoring. J Stroke Cerebrovasc Dis 2016;25:136143.
108. Debing $E$, Van den Brande P. Carotid endarterectomy in the elderly: are the patient characteristics, the early outcome, and the predictors the same as those in younger patients? Surg Neurol 2007;67:467-471.

109. Debing $E$, Aerden $D$, van den Brande P. Diabetes mellitus is a predictor for early adverse outcome after carotid endarterectomy. Vasc Endovascular Surg 2011;45:28-32.

110. Deiwick M, Tandler R, Möllhoff T, Kerber S, Rötker J, Roeder $N$, et al. Heart surgery in patients aged eighty years and above: determinants of morbidity and mortality. Thorac Cardiovasc Surg 1997;45:119-126.

111. Deng Y, Sun Z, Paterson HS. Total arterial revascularisation in left ventricular dysfunction. J Huazhong Univ Sci Technolog Med Sci 2006;26:82-85.

112. Detter $C$, Reichenspurner $H_{1}$ Boehm DH, Thalhammer $M$, Raptis $P$, Schütz $A$, et al. Minimally invasive direct coronary artery bypass grafting (MIDCAB) and off-pump coronary artery bypass grafting (OPCAB): two techniques for beating heart surgery. Heart Surg Forum 2002;5:157-162.

113. VISION Pilot Study Investigators, Devereaux PJ, Bradley D, Chan MT, Walsh M, Villar JC, et al. An international prospective cohort study evaluating major vascular complications among patients undergoing noncardiac surgery: the VISION Pilot Study. Open Med 2011;5:e193-e200.

114. Di Biase L, Gaita F, Toso E, Santangeli P, Mohanty P, Rutledge N, et al. Does periprocedural anticoagulation management of atrial fibrillation affect the prevalence of silent thromboembolic lesion detected by diffusion cerebral magnetic resonance imaging in patients undergoing radiofrequency atrial fibrillation ablation with open irrigated catheters?: results from a prospective multicenter study. Heart Rhythm 2014;11:791-798.

115. Didier R, Gaglia MA Jr, Koifman E, Kiramijyan S, Negi SI, Omar AF, et al. Cerebrovascular accidents after percutaneous coronary interventions from 2002 to 2014: incidence, outcomes, and associated variables. Am Heart J 2016;172:8087.

116. Dinkel M, Schweiger H, Goerlitz P. Monitoring during carotid surgery: somatosensory evoked potentials vs. carotid stump pressure. J Neurosurg Anesthesiol 1992;4:167-175.

117. Donaldson MC, Ivarsson BL, Mannick JA, Whittemore AD. Impact of completion angiography on operative conduct and results of carotid endarterectomy. Ann Surg 1993;217:682687.

118. Dong $H$, Jiang $X$, Peng $M$, Zou $Y$, Che $W$, Qian $H$, et al. The interval between carotid artery stenting and open heart surgery is related to perioperative complications. Catheter Cardiovasc Interv 2016;87 Suppl 1:564-569.

119. Dong S, Peng Z, Tao Y, Huo Y, Zhou H. Metabolic syndrome is 
associated with increased risk of short-term post-procedural complications after carotid artery stenting. Neurol Sci 2017; 38:1933-1939.

120. Dorigo W, Pulli R, Marek J, Troisi N, Pratesi G, Innocenti AA, et al. Carotid endarterectomy in female patients. J Vasc Surg 2009;50:1301-1307.

121. Lam RC, Lin SC, DeRubertis B, Hynecek R, Kent KC, Faries PL. The impact of increasing age on anatomic factors affecting carotid angioplasty and stenting. J Vasc Surg 2007;45:875880.

122. Larsen SF, Zaric D, Boysen G. Postoperative cerebrovascular accidents in general surgery. Acta Anaesthesiol Scand 1988;32:698-701.

123. Lee JD, Bonaros N, Hong PT, Kofler M, Srivastava M, Herr DL, et al. Factors influencing hospital length of stay after robotic totally endoscopic coronary artery bypass grafting. Ann Thorac Surg 2013;95:813-818.

124. Lennard N, Smith JL, Gaunt ME, Abbott RJ, London NJ, Bell $\mathrm{PR}$, et al. A policy of quality control assessment helps to reduce the risk of intraoperative stroke during carotid endarterectomy. Eur J Vasc Endovasc Surg 1999;17:234-240.

125. Liapis CD, Kakisis JD, Kostakis AG. Recurrent carotid artery stenosis: natural history and predisposing factors: a longterm follow-up study. Int Angiol 2001;20:330-336.

126. Likosky DS, Leavitt BJ, Marrin CA, Malenka DJ, Reeves AG, Weintraub RM, et al. Intra- and postoperative predictors of stroke after coronary artery bypass grafting. Ann Thorac Surg 2003;76:428-435.

127. Van der Linden J, Bergman P, Hadjinikolaou L. The topography of aortic atherosclerosis enhances its precision as a predictor of stroke. Ann Thorac Surg 2007;83:2087-2092.

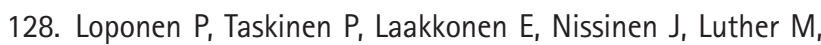
Wistbacka JO. Perioperative stroke in coronary artery bypass patients. Scand J Surg 2003;92:148-155.

129. Love A, Hollyoak MA. Carotid endarterectomy and local anaesthesia: reducing the disasters. Cardiovasc Surg 2000;8: 429-435.

130. Lübke T, Ahmad W, Koushk Jalali B, Brunkwall J. Genderbased 30-day and long-term outcomes after carotid endarterectomy. Vasa 2015;44:289-295.

131. MacDonald P, Stadnyk K, Cossett J, Klassen G, Johnstone D, Rockwood K. Outcomes of coronary artery bypass surgery in elderly people. Can J Cardiol 1998;14:1215-1222.

132. Mandeville $Y$, Canovai $E$, Diebels I, Suy R, De Vleeschauwer P. Carotid bifurcation resection and interposition of a polytetrafluorethylene graft (BRIG) for carotid disease: a retrospective study of 153 consecutive procedures. Ann Vasc Surg 2015;29:1589-1597.
133. Mattos MA, Hodgson KJ, Londrey GL, Barkmeier LD, Ramsey $D E$, Garfield $M$, et al. Carotid endarterectomy: operative risks, recurrent stenosis, and long-term stroke rates in a modern series. J Cardiovasc Surg (Torino) 1992;33:387-400.

134. McCollum PT, da Silva A, Ridler BD, de Cossart L. Carotid endarterectomy in the U.K. and Ireland: audit of 30-day outcome. The Audit Committee for the Vascular Surgical Society. Eur J Vasc Endovasc Surg 1997;14:386-391.

135. McKhann GM, Grega MA, Borowicz LM Jr, Bechamps $M$, Selnes OA, Baumgartner WA, et al. Encephalopathy and stroke after coronary artery bypass grafting: incidence, consequences, and prediction. Arch Neurol 2002;59:1422-1428.

136. Mitchell RS, Miller DC, Dake MD, Semba CP, Moore KA, Sakai T. Thoracic aortic aneurysm repair with an endovascular stent graft: the "first generation". Ann Thorac Surg 1999;67: 1971-1980.

137. Mukerji N, Manjunath Prasad KS, Vivar R, Mendelow AD. Carotid endarterectomy: safe and effective in a neurosurgeon's hands: a 25-year single-surgeon experience. World Neurosurg 2015;83:74-79.

138. Mullenix PS, Andersen CA, Olsen SB, Tollefson DF. Carotid endarterectomy remains the gold standard. Am J Surg 2002; 183:580-583.

139. Naylor AR, Hayes PD, Allroggen $H$, Lennard $N$, Gaunt ME, Thompson MM, et al. Reducing the risk of carotid surgery: a 7-year audit of the role of monitoring and quality control assessment. J Vasc Surg 2000;32:750-759.

140. Newman MF, Wolman R, Kanchuger M, Marschall K, MoraMangano $C$, Roach $G$, et al. Multicenter preoperative stroke risk index for patients undergoing coronary artery bypass graft surgery. Multicenter Study of Perioperative Ischemia (McSPI) Research Group. Circulation 1996;94(9 Suppl):II74-II80.

141. Nicholls SC, Phillips DJ, Bergelin RO, Beach KW, Primozich JF, Strandness DE Jr. Carotid endarterectomy: relationship of outcome to early restenosis. J Vasc Surg 1985;2:375-381.

142. Nordanstig A, Rosengren L, Strömberg $S$, Österberg K, Karlsson $L$, Bergström G, et al. Editor's choice: very urgent carotid endarterectomy is associated with an increased procedural risk: the carotid alarm study. Eur J Vasc Endovasc Surg 2017;54:278286.

143. Ott DA, Cooley DA, Chapa L, Coelho A. Carotid endarterectomy without temporary intraluminal shunt: study of 309 consecutive operations. Ann Surg 1980;191:708-714.

144. Pell JP, Slack R, Dennis M, Welch G. Improvements in carotid endarterectomy in Scotland: results of a national prospective survey. Scott Med J 2004;49:53-56.

145. Radu H, Bertog SC, Robertson G, Franke J, Rabe K, Hornung $M$, et al. Long-term results after carotid stent implantation. $J$ 
Interv Cardiol 2013;26:613-622.

146. Rafiq S, Johansson PI, Ostrowski SR, Stissing T, Steinbrüchel DA. Hypercoagulability in patients undergoing coronary artery bypass grafting: prevalence, patient characteristics and postoperative outcome. Eur J Cardiothorac Surg 2012;41: 550-555.

147. Roach GW, Kanchuger M, Mangano CM, Newman M, Nussmeier N, Wolman R, et al. Adverse cerebral outcomes after coronary bypass surgery: Multicenter Study of Perioperative Ischemia Research Group and the Ischemia Research and Education Foundation Investigators. N Engl J Med 1996;335: 1857-1863.

148. Saini $A, H u$ YL, Kasirajan V, Han FT, Khan MZ, Wolfe $L$, et al. Long-term outcomes of minimally invasive surgical ablation for atrial fibrillation: a single-center experience. Heart Rhythm 2017;14:1281-1288.

149. Salazar JD, Wityk RJ, Grega MA, Borowicz LM, Doty JR, Petrofski JA, et al. Stroke after cardiac surgery: short- and long-term outcomes. Ann Thorac Surg 2001;72:1195-1202.

150. Salem MK, Sayers RD, Bown MJ, Eveson DJ, Robinson TG, Naylor AR. Rapid access carotid endarterectomy can be performed in the hyperacute period without a significant increase in procedural risks. Eur J Vasc Endovasc Surg 2011;41:222-228.

151. Samson RH, Showalter DP, Yunis JP. Routine carotid endarterectomy without a shunt, even in the presence of a contralateral occlusion. Cardiovasc Surg 1998;6:475-484.

152. Sandison A, Wood CH, Padayachee TS, Colchester AC, Taylor PR. Cost-effective carotid endarterectomy. Br J Surg 2000;87: 323-327.

153. De Santo LS, Bancone C, Santarpino G, Romano G, De Feo M, Scardone $M$, et al. Microbiologically documented nosocomial infections after cardiac surgery: an 18-month prospective tertiary care centre report. Eur J Cardiothorac Surg 2008;33: 666-672.

154. Schmitz C, Weinreich S, White J, Oengoeren I, Schneider R, Schneider $D$, et al. Can particulate extraction from the ascending aorta reduce neurologic injury in cardiac surgery? J Thorac Cardiovasc Surg 2003;126:1829-1838.

155. Schneider JR, Droste JS, Golan JF. Impact of carotid endarterectomy critical pathway on surgical outcome and hospital stay. Vasc Endovascular Surg 1997;31:685-692.

156. Schoenefeld E, Donas K, Radicke A, Osada N, Austermann M, Torsello G. Perioperative use of aspirin for patients undergoing carotid endarterectomy. Vasa 2012;41:282-287.

157. Schoof J, Lubahn W, Baeumer M, Kross R, Wallesch CW, Kozian $A$, et al. Impaired cerebral autoregulation distal to carotid stenosis/occlusion is associated with increased risk of stroke at cardiac surgery with cardiopulmonary bypass. $J$
Thorac Cardiovasc Surg 2007;134:690-696.

158. Senay $S$, Toraman F, Akgün $Y$, Aydin E, Karabulut H, Alhan C, et al. Stroke after coronary bypass surgery is mainly related to diffuse atherosclerotic disease. Heart Surg Forum 2011;14: E366-E372.

159. Shapira OM, Hunter CT, Anter E, Bao Y, DeAndrade K, Lazar $\mathrm{HL}$, et al. Coronary artery bypass grafting in patients with severe left ventricular dysfunction: early and mid-term outcomes. J Card Surg 2006;21:225-232.

160. Shaw PJ, Bates D, Cartlidge NE, Heaviside D, Julian DG, Shaw DA. Early neurological complications of coronary artery bypass surgery. Br Med J (Clin Res Ed) 1985;291:1384-1387.

161. Spes $C H$, Schwende $A$, Beier $F$, Hug M, Hein $R$, Strohm $H$, et al. Short- and long-term outcome after carotid artery stenting with neuroprotection: single-center experience within a prospective registry. Clin Res Cardiol 2007;96:812-821.

162. Stabile E, Salemme L, Sorropago G, Tesorio T, Nammas W, Miranda $\mathrm{M}$, et al. Proximal endovascular occlusion for carotid artery stenting: results from a prospective registry of 1,300 patients. J Am Coll Cardiol 2010;55:1661-1667.

163. Subban V, Murdoch D, Savage ML, Crowhurst J, Saireddy R, Poon KK, et al. Outcomes of transcatheter aortic valve implantation in high surgical risk and inoperable patients with aortic stenosis: a single Australian Centre experience. Intern Med J 2016;46:42-51.

164. Suematsu Y, Nakano K, Sasako Y, Kobayashi J, Takamoto S. Strategies for CABG patients with carotid artery disease and perioperative neurological complications. Heart Vessels 2000; 15:129-134.

165. Takach TJ, Ott DA, Reul GJ, Duncan JM, Livesay JJ, Cooley DA. Carotid endarterectomy: results in asymptomatic and symptomatic patients. Tex Heart Inst J 1996;23:42-44.

166. Tatoulis J, Buxton BF, Fuller JA, Royse AG. Total arterial coronary revascularization: techniques and results in 3,220 patients. Ann Thorac Surg 1999;68:2093-2099.

167. Trehan N, Mishra M, Dhole S, Mishra A, Karlekar A, Kohli VM. Significantly reduced incidence of stroke during coronary artery bypass grafting using transesophageal echocardiography. Eur J Cardiothorac Surg 1997;11:234-242.

168. Trehan N, Mishra M, Kasliwal RR, Mishra A. Reduced neurological injury during $C A B G$ in patients with mobile aortic atheromas: a five-year follow-up study. Ann Thorac Surg 2000;70:1558-1564.

169. Verhoeven BA, de Vries JP, Pasterkamp G, Ackerstaff RG, Schoneveld $A H$, Velema $E_{\text {, et }}$ al. Carotid atherosclerotic plaque characteristics are associated with microembolization during carotid endarterectomy and procedural outcome. Stroke 2005;36:1735-1740. 
170. Veselka J, Cerná D, Zimolová P, Martinkovicová L, Fiedler J, Hájek $P$, et al. Feasibility, safety, and early outcomes of direct carotid artery stent implantation with use of the FilterWire EZ Embolic Protection System. Catheter Cardiovasc Interv 2009;73:733-738.

171. Executive Committee for the Asymptomatic Carotid Atherosclerosis Study. Endarterectomy for asymptomatic carotid artery stenosis. JAMA 1995;273:1421-1428.

172. Walkes JC, Earle N, Reardon MJ, Glaeser DH, Wall MJ Jr, Huh $J$, et al. Outcomes in single versus bilateral internal thoracic artery grafting in coronary artery bypass surgery. Curr Opin Cardiol 2002;17:598-601.

173. Weimar T, Schena S, Bailey MS, Maniar HS, Schuessler RB, Cox JL, et al. The cox-maze procedure for lone atrial fibrillation: a single-center experience over 2 decades. Circ Arrhythm Electrophysiol 2012;5:8-14.

174. Weinstein GS. Left hemispheric strokes in coronary surgery: implications for end-hole aortic cannulas. Ann Thorac Surg $2001 ; 71: 128-132$.

175. Wenaweser P, Pilgrim T, Guerios E, Stortecky S, Huber $C_{1}$ Khattab $A A$, et al. Impact of coronary artery disease and percutaneous coronary intervention on outcomes in patients with severe aortic stenosis undergoing transcatheter aortic valve implantation. Eurolntervention 2011;7:541-548.

176. Burns RJ, Willoughby JO. South Australian carotid endarterectomy study. Med J Aust 1991;154:650-653.

177. Wöhrle J, Gonska B, Rodewald C, Seeger J, Scharnbeck D, Rottbauer W. Transfemoral aortic valve implantation with the New Edwards Sapien 3 valve for treatment of severe aortic stenosis: impact of valve size in a single center experience. PLoS One 2016;11:e0151247.

178. Woelfle KD, Bruijnen $H_{1}$ Neu J, Campbell P, Wack C, Loeprecht $\mathrm{H}$. The role of intraoperative digital subtraction angiography for quality control of standard carotid endarterectomy using patch angioplasty. Cardiovasc Surg 2002;10:116-122.

179. Wolman RL, Nussmeier NA, Aggarwal A, Kanchuger MS, Roach GW, Newman MF, et al. Cerebral injury after cardiac surgery: identification of a group at extraordinary risk. Multicenter Study of Perioperative Ischemia Research Group
(McSPI) and the Ischemia Research Education Foundation (IREF) Investigators. Stroke 1999;30:514-522.

180. Wong JH, Lubkey TB, Suarez-Almazor ME, Findlay JM. Improving the appropriateness of carotid endarterectomy: results of a prospective city-wide study. Stroke 1999;30:12-15.

181. Yadeau JT, Casciano M, Liu SS, Edmonds CR, Gordon M, Stanton J, et al. Stroke, regional anesthesia in the sitting position, and hypotension: a review of 4169 ambulatory surgery patients. Reg Anesth Pain Med 2011;36:430-435.

182. Young B, Moore WS, Robertson JT, Toole JF, Ernst CB, Cohen $\mathrm{SN}$, et al. An analysis of perioperative surgical mortality and morbidity in the asymptomatic carotid atherosclerosis study. ACAS Investigators. Asymptomatic Carotid Atherosclerosis Study. Stroke 1996;27:2216-2224.

183. Zannetti S, Cao P, De Rango P, Giordano G, Parlani G, Lenti $M$, et al. Intraoperative assessment of technical perfection in carotid endarterectomy: a prospective analysis of 1305 completion procedures. Collaborators of the EVEREST study group. Eversion versus standard carotid endartectomy. Eur J Vasc Endovasc Surg 1999;18:52-58.

184. Zarins CK, White RA, Diethrich EB, Shackelton RJ, Siami FS; CaRESS Steering Committee and CaRESS Investigators. Carotid revascularization using endarterectomy or stenting systems (CaRESS): 4-year outcomes. J Endovasc Ther 2009;16: 397409.

185. Zhang L, Bassin L, Cranney G, Lau A, Akhunji Z, Wolfenden H, et al. Aortic valve replacement after previous cardiac surgery. Heart Lung Circ 2015;24 Suppl 1:e21-e22.

186. Ziemann $M$, Heringlake $M$, Lenor $P$, Juhl $D$, Hanke $T$, Petersen $M$, et al. Cytomegalovirus serostatus as predictor for adverse events after cardiac surgery: a prospective observational study. J Cardiothorac Vasc Anesth 2017;31:2042-2048.

187. Zipfel B, Buz S, Hammerschmidt R, Krabatsch T, Duesterhoeft $\mathrm{V}$, Hetzer R. Early clinical experience with the E-vita thoracic stent-graft system: a single center study. J Cardiovasc Surg (Torino) 2008;49:417-428.

188. Moher D, Liberati A, Tetzlaff J, Altman DG; PRISMA Group. Preferred reporting items for systematic reviews and meta-analyses: the PRISMA statement. PLoS Med 2009;6:e1000097. 